U.S. Department of Energy

FreedomCAR and Vehicle Technologies, EE-2G

1000 Independence Avenue, S.W.

Washington, D.C. 20585-0121

FY 2006

\title{
EVALUATION OF 2005 HONDA ACCORD HYBRID ELECTRIC DRIVE SYSTEM
}

Prepared by:

Oak Ridge National Laboratory

Mitch Olszewski, Program Manager

\section{Submitted to:}

Energy Efficiency and Renewable Energy

FreedomCAR and Vehicle Technologies

Vehicle Systems Team

Susan A. Rogers, Technology Development Manager

September 2006 
NATIONAL LABORATORY

MANAGED BY UT-BATTELLE

FOR THE DEPARTMENT OF ENERGY
Engineering Science and Technology Division

\section{EVALUATION OF 2005 HONDA ACCORD HYBRID ELECTRIC DRIVE SYSTEM}

\author{
R. H. Staunton \\ T. A. Burress \\ L. D. Marlino
}

Publication Date: September 2006

Prepared by the OAK RIDGE NATIONAL LABORATORY

Oak Ridge, Tennessee 37831

managed by

UT-BATTELLE, LLC for the

U.S. DEPARTMENT OF ENERGY Under contract DE-AC05-00OR22725 


\section{DOCUMENT AVAILABILITY}

Reports produced after January 1, 1996, are generally available free via the U.S. Department of Energy (DOE) Information Bridge:

Web site: http://www.osti.gov/bridge

Reports produced before January 1, 1996, may be purchased by members of the public from the following source:

National Technical Information Service

5285 Port Royal Road

Springfield, VA 22161

Telephone: 703-605-6000 (1-800-553-6847)

TDD: $703-487-4639$

Fax: 703-605-6900

E-mail: info@ ntis.fedworld.gov

Web site: http://www.ntis.gov/support/ordernowabout.htm

Reports are available to DOE employees, DOE contractors, Energy Technology Data Exchange (ETDE) representatives, and International Nuclear Information System (INIS) representatives from the following source:

Office of Scientific and Technical Information

P.O. Box 62

Oak Ridge, TN 37831

Telephone: 865-576-8401

Fax: 865-576-5728

E-mail: reports@osti.gov

Web site: http://www.osti.gov/contact.html

This report was prepared as an account of work sponsored by an agency of the United States Government. Neither the United States government nor any agency thereof, nor any of their employees, makes any warranty, express or implied, or assumes any legal liability or responsibility for the accuracy, completeness, or usefulness of any information, apparatus, product, or process disclosed, or represents that its use would not infringe privately owned rights. Reference herein to any specific commercial product, process, or service by trade name, trademark, manufacturer, or otherwise, does not necessarily constitute or imply its endorsement, recommendation, or favoring by the United States Government or any agency thereof. The views and opinions of authors expressed herein do not necessarily state or reflect those of the United States Government or any agency thereof. 


\section{TABLE CONTENTS}

Page

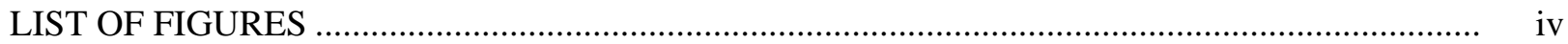

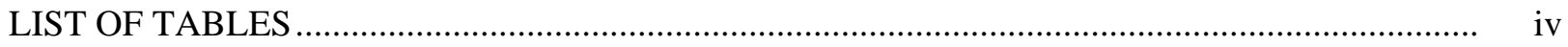

ACRONYMS AND ABBREVIATIONS ……........................................................................... v

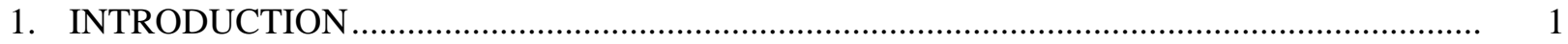

2. HYBRID ELECTRIC DRIVE SYSTEM DESIGN AND PACKAGING ….............................

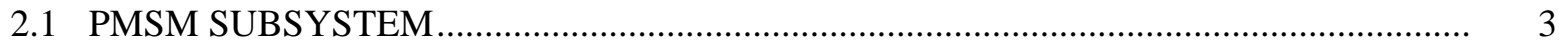

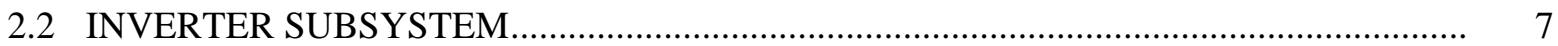

3. BENCHMARKING TESTS OF ACCORD PMSM AND INVERTER ...................................... 10

3.1 SUBSYSTEM PREPARATION FOR TESTING

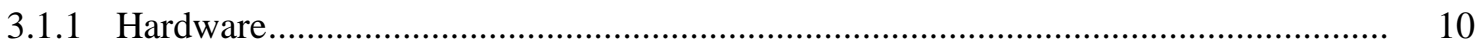

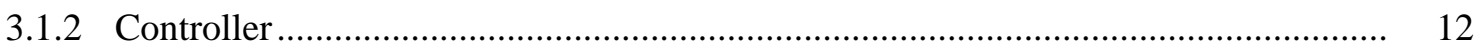

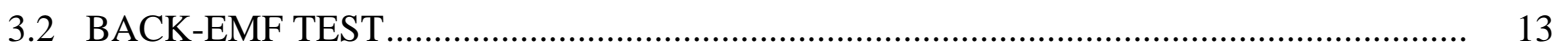

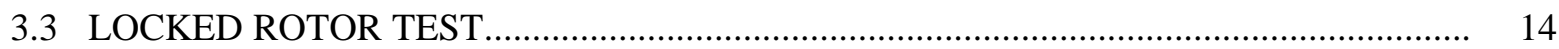

3.4 PERFORMANCE MAPPING TEST ……................................................................. 16

3.5 EXTENDED-DURATION LOAD TEST ...................................................................... 19

4. SUMMARY AND RECOMMENDATIONS …......................................................................

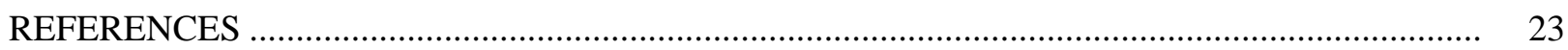

APPENDIX A - COMPARISONS OF ACCORD AND PRIUS EFFICIENCY MAPS .................... 24 


\section{LIST OF FIGURES}

Figure

Page

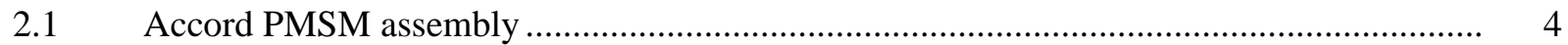

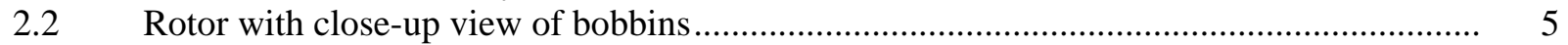

2.3 Stator disassembly showing daisy-chain lamination design ......................................... 5

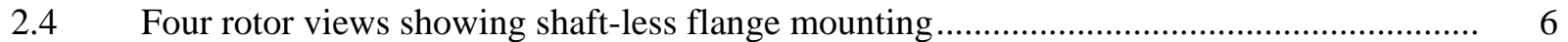

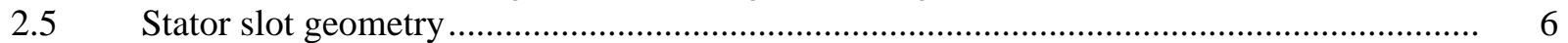

2.6 Inverter control module and inverter driver board and heat sink assembly ....................... 8

$2.7 \quad$ Inverter assembly with protective cover removed.......................................................... 8

2.8 Size comparison of selected blower system components and inverter ............................ 9

3.1 Accord motor with custom-designed end plates and shaft .......................................... 10

3.2 Bonding of a TC between two adjacent stator windings .................................................... 10

3.3 Location of TCs on the inverter heat sink ..................................................................

3.4 Preparation of test cell for Accord performance testing ................................................... 11

3.5 Test cell equipment supporting Accord performance testing .......................................... 12

3.6 Average line-to-neutral back-emf vs. shaft speed (2005 Accord motor)............................. 13

3.7 Magnetic torque vs. electrical position at varying levels of stator current ........................ 15

3.8 Maximum magnetic torque vs. stator current (locked-rotor test) ...................................... 15

3.9 2005 Accord motor efficiency contour map ................................................................... 17

3.10 2005 Accord inverter efficiency contour map ................................................................. 18

3.112005 Accord motor-plus-inverter efficiency contour map ............................................. 19

S.12 Stator winding temperature and torque vs. time .......................................................... 20

A.1 Comparison of Accord and Prius motor efficiency contour maps..................................... 25

A.2 Comparison of Accord and Prius inverter efficiency contour maps................................... 26

A.3 Comparison of Accord and Prius motor plus inverter efficiency contour maps................... 27

\section{LIST OF TABLES}

$2.1 \quad$ Differences between the hybrid Accord and the Prius .................................................... 3

$2.2 \quad$ Summary of physical parameters of the Accord PMSM .................................................. 5

$2.3 \quad$ Key design parameters for the Accord PMSM...................................................................

2.4 Summary of physical parameters of the Accord inverter ..................................................... 9

3.1 Back-emf vs. shaft speed data (2005 Accord motor)....................................................... 14

3.2 Maximum torque vs. stator current................................................................................. 16

4.1 Comparison of key subsystem parameters for the Accord and Prius ................................. 21 


\section{ACRONYMS AND ABBREVIATIONS}

\begin{tabular}{|c|c|c|c|}
\hline ANL & Argonne National Laboratory & $\mathrm{kW}$ & kilowatt \\
\hline CT & current transformer & $\mathrm{L}$ & liter \\
\hline dc & direct current & $\mathrm{mm}$ & millimeter \\
\hline DOE & U.S. Department of Energy & NiMH & neodymium iron boron \\
\hline ECU & electronic-control unit & NTRC & National Transportation \\
\hline emf & electromotive force (measured in volts) & & Research Center \\
\hline EMI & electromagnetic interference & $\mathrm{Nm}$ & Newton meter \\
\hline FCVT & FreedomCAR and Vehicle Technologies & ORNL & Oak Ridge National Laboratory \\
\hline $\mathrm{HEV}$ & hybrid electric vehicle & PEEMRC & Power Electronics and Electric \\
\hline $\mathrm{HV}$ & high voltage & & Machinery Research Center \\
\hline$i_{d}$ & direct-axis current & PI & proportional-integral \\
\hline & quadrature-axis current & PM & permanent magnet \\
\hline IGBT & insulated-gate bipolar transistor & PMSM & permanent magnet synchronous motor \\
\hline IMA & integrated motor assist & rpm & revolutions per minute \\
\hline IPM & internal permanent magnet & TC & thermal cou \\
\hline $\mathrm{kg}$ & kilogram & TPM & transfer-mode power moc \\
\hline
\end{tabular}




\section{INTRODUCTION}

The Hybrid Electric Vehicle (HEV) program officially began in 1993 as a five-year, cost-shared partnership between the U.S. Department of Energy (DOE) and American auto manufacturers: General Motors, Ford, and DaimlerChrysler. Currently, HEV research and development is conducted by DOE through its FreedomCAR and Vehicle Technologies (FCVT) program. The mission of the FCVT program is to develop more energy efficient and environmentally friendly highway transportation technologies. Program activities include research, development, demonstration, testing, technology validation, and technology transfer. These activities are aimed at developing technologies that can be domestically produced in a clean and cost-competitive manner.

The vehicle systems technologies subprogram, which is one of four subprograms under the FCVT program, supports the efforts of the FreedomCAR through a three-phase approach [1] intended to:

- Identify overall propulsion and vehicle-related needs by analyzing programmatic goals and reviewing industry's recommendations and requirements, then develop the appropriate technical targets for systems, subsystems, and component research and development activities;

- Develop and validate individual subsystems and components, including electric motors, emission control devices, battery systems, power electronics, accessories, and devices to reduce parasitic losses; and

- Determine how well the components and subassemblies work together in a vehicle environment or as a complete propulsion system and whether the efficiency and performance targets at the vehicle level have been achieved.

The research performed under the vehicle systems subprogram will help remove technical and cost barriers to enable technology for use in such advanced vehicles as hybrid electric, plug-in electric, and fuel-cell-powered vehicles.

The Oak Ridge National Laboratory’s (ORNL) Power Electronics and Electric Machinery Research Center (PEEMRC) performed benchmark assessments and subsystem testing of the 2004 Toyota Prius in 2004-2005. This work has been fully reported to the FCVT program members in two reports [2,3]. This year, the PEEMRC has performed similar work on the hybrid version of the 2005 Honda Accord

The 2005 Honda Accord hybrid is equipped with a gasoline engine and a battery- and inverter-powered electric motor. The electric motor assists the engine in providing mechanical drive power for the vehicle and also acts as a generator for battery recharging. The motor can deliver a peak power output of 12 kilowatt $(\mathrm{kW})$ over the speed range of 983-6500 revolutions per minute (rpm). The engine has a specified peak power output of 240 hp @ 6000 rpm from the standard 3-liter, V6 engine [4].

The redesigned Honda Accord for 2006 makes use of a motor that is still rated at $12 \mathrm{~kW}$ according to Honda sources [5], although other sources [6] quote a $14 \mathrm{~kW}$ rating that applies only to its electrical generation mode for charging the high-voltage (HV) battery.

Unlike the Toyota Prius, which is considered to be a full hybrid, the Accord with its smaller motor is considered to be a "mild hybrid" since the motor never propels the vehicle without engine power. In operation, the 2005 Accord exhibits enhanced performance compared to the conventionally powered Accord, but little or no gain in fuel economy. 
To acquire an improved understanding of the motor assist technology used in the 2005 Accord, a design characterization study was conducted to evaluate the vehicle's hybrid electric drive subsystem. The characterization study included (1) a design review, (2) a packaging and fabrication assessment, (3) bench-top electrical tests, (4) back-electromotive force (emf) and locked rotor tests, and (5) a fulldesign-range performance test of the motor and inverter. This final performance test effectively mapped the electrical and thermal results for motor/inverter operation over the full range of speeds and shaft loads that these assemblies are designed for in the Accord. This enabled ORNL to map the efficiency of the subsystems. The design and packaging review includes comparisons to the 2004 Toyota Prius, which was evaluated during previous years.

Evaluation of the 2005 Accord and its hybrid electric drive system involved subassembly-level performance testing. Subassembly-level testing was conducted by ORNL at its PEEMRC, which is a broad-based research center for power electronics and electric machinery (motor) development. Located in the recently constructed national user facility known as the National Transportation Research Center (NTRC), the PEEMRC has more than 9000 square feet of space for developing and building the next generation prototypes of power electronics, and electric machine technologies. 


\section{HYBRID ELECTRIC DRIVE SYSTEM DESIGN AND PACKAGING}

The 2005 hybrid Accord is an example of how the automotive industry is introducing hybrid technology to preexisting vehicle models. This Accord design is considered to be a "mild hybrid" due to the small power rating of the integrated motor assist (IMA) and the fact that it is used only for acceleration assist to the engine. The permanent magnet synchronous motor (PMSM)/inverter system is not used for acceleration without engine power as in the case of a "strong hybrid." After the vehicle reaches highway speeds, the IMA is used to contribute torque during moderate or strong accelerations.

In contrast, the Prius was designed from the beginning to be a hybrid vehicle and is considered to be a "strong hybrid." Many of the significant Accord-verses-Prius design differences are summarized in Table 2.1.

Table 2.1. Differences between the hybrid Accord and the Prius

\begin{tabular}{|c|c|c|}
\hline Design Feature & Hybrid Accord & Prius \\
\hline Motor peak power rating, $\mathrm{kW}$ & $12.4 @ 840$ rpm & $50 @ 1200-1540$ rpm \\
\hline $\begin{array}{l}\text { Motor peak torque rating, } \\
\text { Newton meter }(\mathrm{Nm})\end{array}$ & 136 & 400 \\
\hline Separate generator & No & $\begin{array}{c}\text { Yes (although the motor also } \\
\text { serves as a generator) }\end{array}$ \\
\hline $\begin{array}{l}\text { PMSM used for initial } \\
\text { acceleration }\end{array}$ & Engine assist & Exclusively \\
\hline Source of power to PMSM & Battery & Generator and battery \\
\hline Purpose of the hybrid system & Primarily performance & $\begin{array}{l}\text { Primarily improved fuel } \\
\text { economy }\end{array}$ \\
\hline PMSM rotor design & $\begin{array}{l}\text { Interior PMs embedded near the rotor } \\
\text { surface }\end{array}$ & $\begin{array}{l}\text { Interior PMs with "V" } \\
\text { configuration at each pole }\end{array}$ \\
\hline Number of rotor poles & 16 & 8 \\
\hline Boost converter used & No & Yes \\
\hline Inverter bus voltage & 144 & $200-500$ \\
\hline PMSM cooling & Passive cooling & Water/glycol loop \\
\hline Inverter cooling & Forced air convection & Water/glycol loop \\
\hline Location of inverter & $\begin{array}{l}\text { Behind rear seat in passenger } \\
\text { compartment }\end{array}$ & Engine compartment \\
\hline Physical integration of the PMSM & $\begin{array}{l}\text { Flat ( } 68 \text { millimeter }[\mathrm{mm}] \text { ) motor-only } \\
\text { assembly located between engine and } \\
\text { torque converter; the rotor shaft is } \\
\text { replaced by dual rotor hubs with bolt } \\
\text { flanges }\end{array}$ & $\begin{array}{l}\text { PMSM is included in an engine- } \\
\text { mounted casing (“axle } \\
\text { assembly”) that contains the } \\
\text { generator and planetary } \\
\text { gear/reduction gear assemblies }\end{array}$ \\
\hline
\end{tabular}

There are also a few important similarities between the two designs. Both use a PMSM with an integral resolver in the rotor and the motors have a top speed of $6000 \mathrm{rpm}$. Both PMSMs not only produce traction power, but also a battery charging current during decelerations and braking.

\subsection{PMSM SUBSYSTEM}

The $12 \mathrm{~kW}$ Accord PMSM is powered by 120-1.2vdc nickel-metal hydride batteries (144 vdc total). The PMSM develops 16 hp @ 840 rpm [4]. The SAE net torque is 100 lb-ft (135.5 Nm) @ 840 rpm [4]. Honda reports the regeneration efficiency of the PMSM to be $95.2 \%$, and the power rating is actually greater for regeneration than for motor operation (14 kW vs. $12 \mathrm{~kW})$. 
Honda reports [7] several design features/innovations in the Accord PMSM in comparison to their Civic design:

- New materials in the stator to enhance flux density

- Thinner laminations in the stator to reduce iron loss

- A large-diameter resolver that is integral to the PMSM rotor

- An internal permanent magnet (IPM) rotor

- Reduction in armature copper loss

- $\quad$ Reduction in flux weakening current

- Thin (68 mm), high-power-density motor packaging.

Figure 2.1 shows the assembly of PMSM rotor, stator, casing, position and speed resolver, and the threephase bus bar/connector assembly. This entire assembly is sandwiched between the engine and the torque converter.

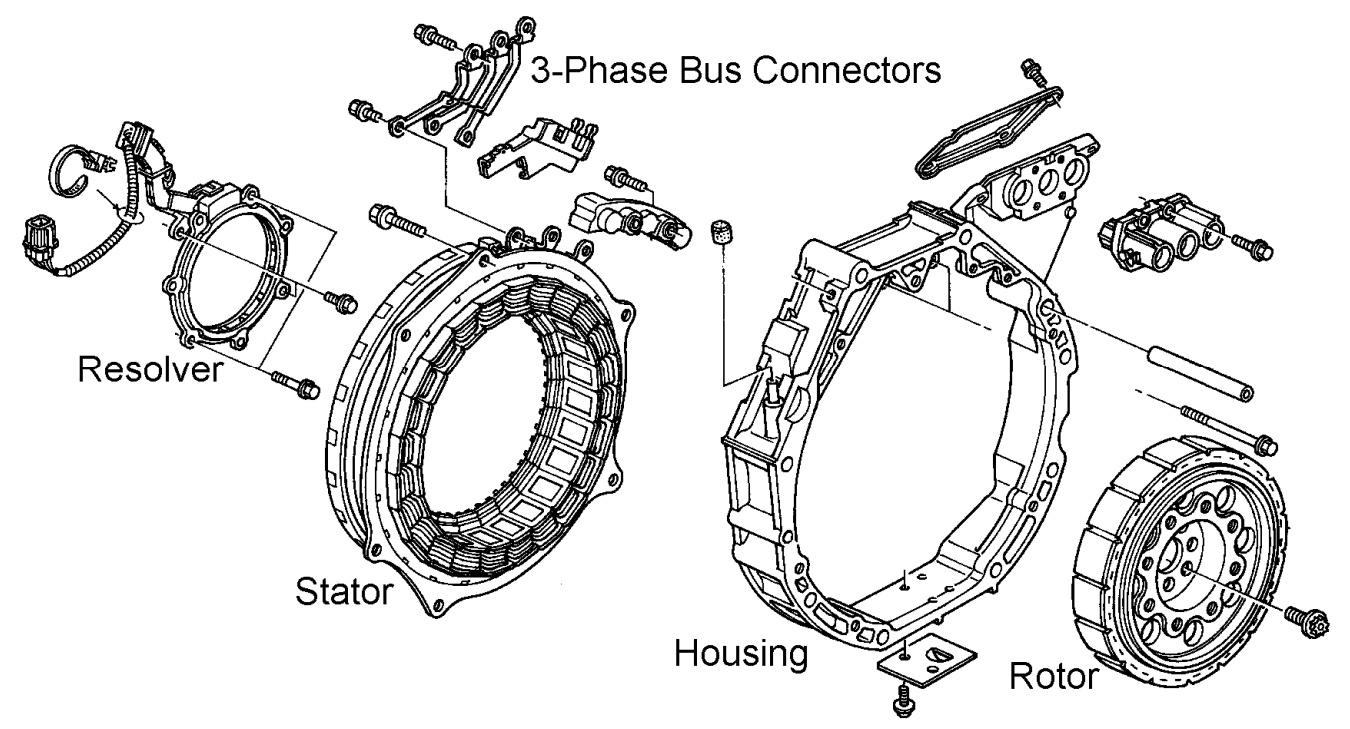

Fig. 2.1. Accord PMSM assembly (adapted from Honda drawing).

Based on an ORNL inspection of the PMSM components, parameters such as masses, volumes, power density, and specific power were determined. This information is summarized in Table 2.2. Note that the power density and specific power are based on the "peak" or non-continuous-duty power rating of the subsystems shown. Since the subsystems are used for certain vehicle acceleration demands, the intermittent power rating may be significantly higher than the continuous rating. The subsystems are basically designed for intermittent duty.

Figure 2.2 shows the Accord PMSM stator with the aluminum casing surrounding it. On the right is a close-up of the bobbin-style windings. Figure 2.3 shows the modular design and assembly of the stator. Small stacks of laminations are assembled for each coil. These are held in place by two plastic shells that are slid over the laminations from the top and bottom of the stack. Each bobbin stack assembly is shaped to hold its position relative to adjacent stacks. The bobbin stack assemblies are held together incidentally by the neutral line and the three-phase wires that circle around the stator and by a flexible compound that holds these four wires and secures the connections. However, the primary mechanical support is the steel containment ring with mounting holes (see left bottom corner of Fig. 2.2). The ring also secures the stator to the aluminum casing. 
Table 2.2. Summary of physical parameters of the Accord PMSM

\begin{tabular}{|l|c|c|}
\hline \multicolumn{1}{|c|}{ Component/Parameter } & $\begin{array}{c}\text { Estimated Value for } \\
\text { the Accord }\end{array}$ & $\begin{array}{c}\text { Prius } \\
\text { (comparison of } \\
\text { key parameters) }\end{array}$ \\
\hline PMSM radius, mm & 191.3 & \\
\hline PMSM thickness, mm & 69.0 & \\
\hline PMSM volume, liter (L) & 7.93 & \\
\hline Peak power density, kW/L & $\mathbf{1 . 5 1}$ & 3.25 \\
\hline Rotor mass, kilogram (kg) & 9.99 & \\
\hline Stator and casing mass, kg & 12.5 & \\
\hline Bus bar and fastener mass, kg & 0.128 & \\
\hline Total PMSM mass, kg & 22.6 & \\
\hline Peak specific power, $\mathbf{k W / k g}$ & $\mathbf{0 . 5 3 2}$ & 1.11 \\
\hline
\end{tabular}
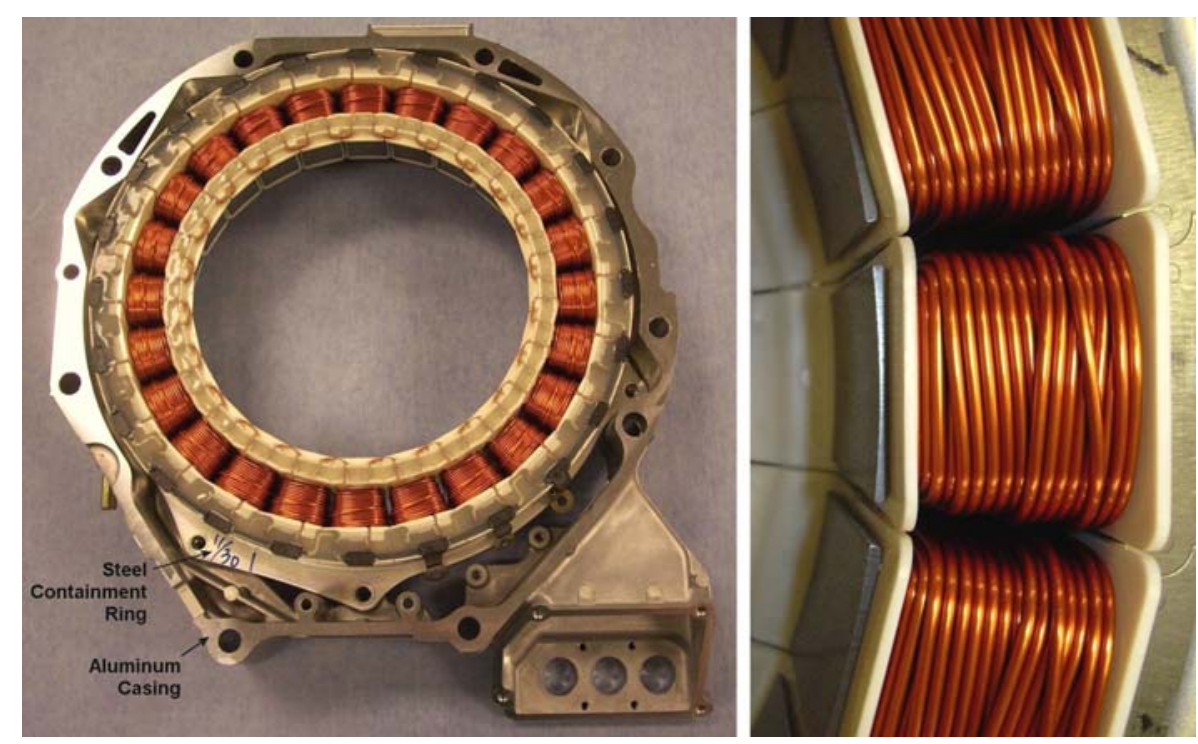

Fig. 2.2. Rotor with close-up view of bobbins.

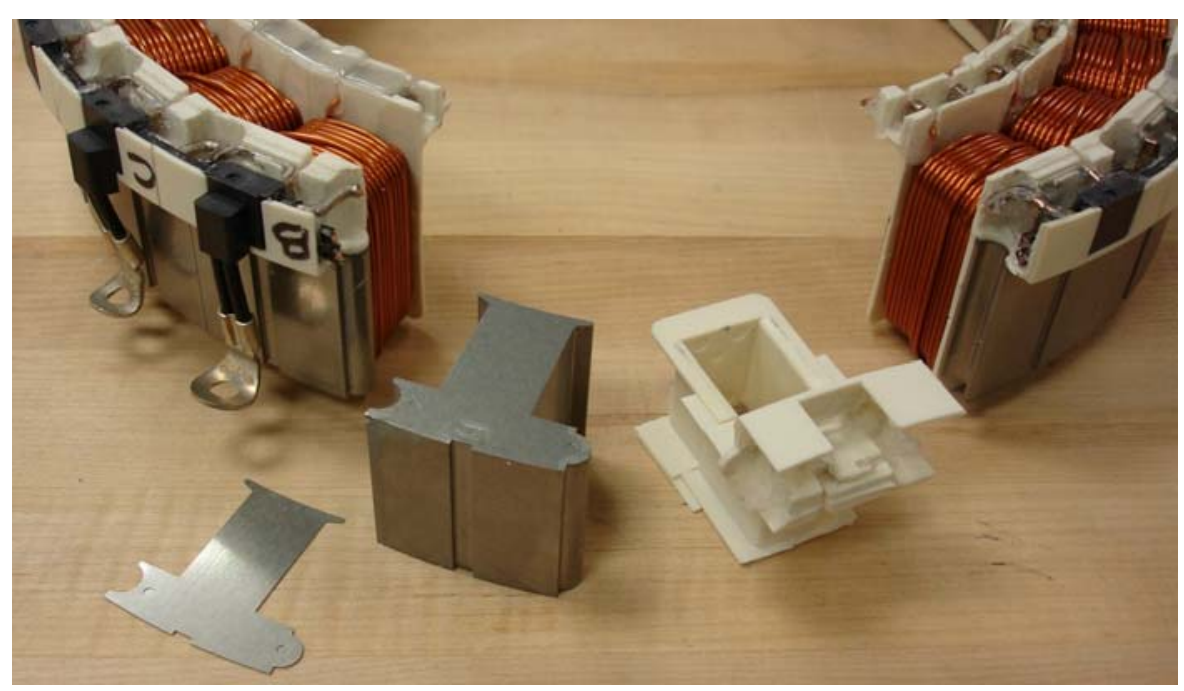

Fig. 2.3. Stator disassembly showing daisy-chain lamination design. 
The two sides of the PMSM rotor are depicted in Fig. 2.4(a) and 2.4(b). The rotor does not use a shaft, but instead the engine shaft bolts to one mounting flange and the torque converter shaft bolts to the other. In Fig. 2.4(a), the lamination ring for the absolute position resolver is seen and a close-up of the lobes is shown in Fig. 2.4(c). Figure 2.4(d) shows the rotor without the lamination end ring and the PM pairs at each pole position. The lamination bridge (or reinforcement rib) between the PM pairs provides the needed mechanical strength at high speeds.

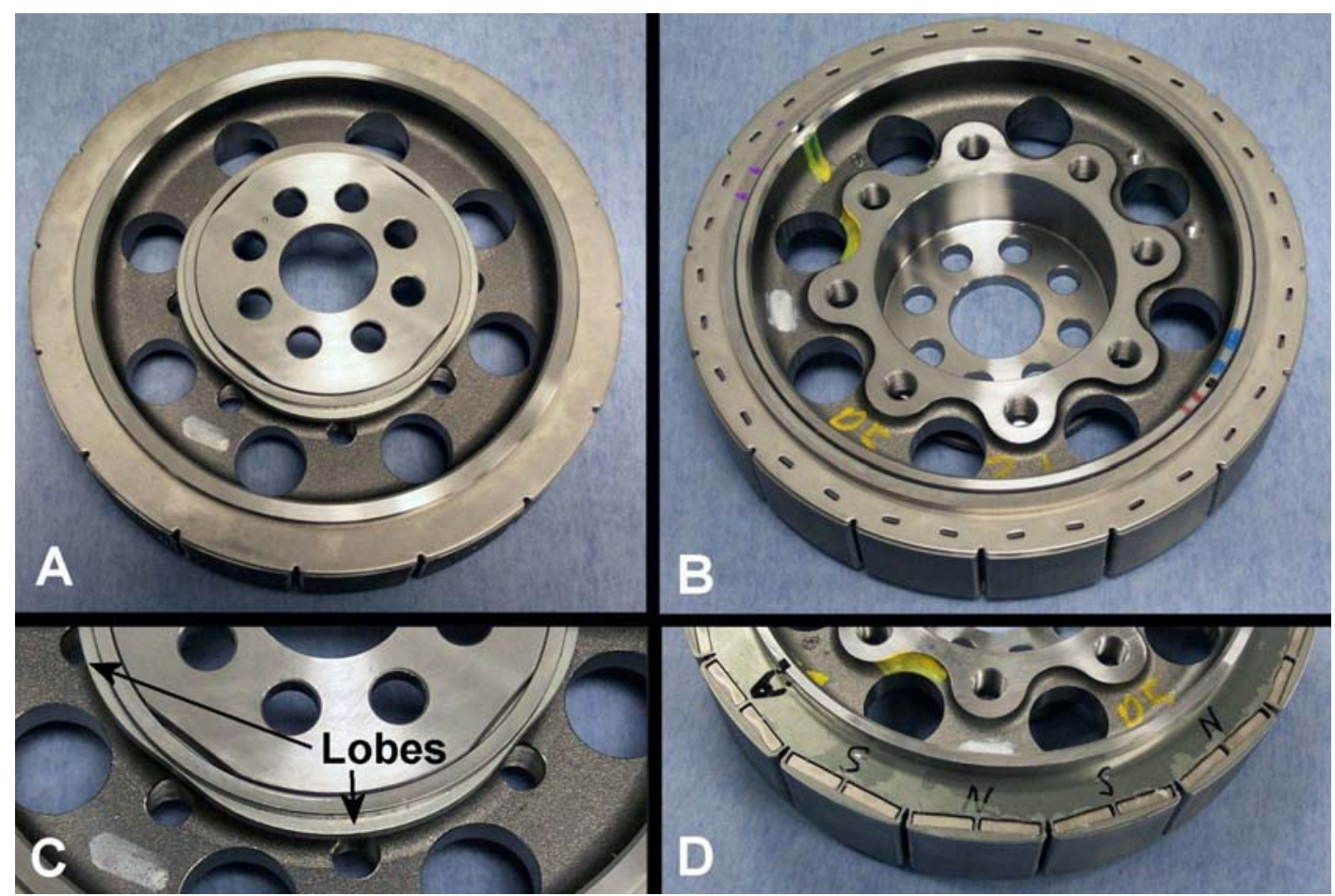

Fig. 2.4. Four rotor views showing shaft-less flange mounting.

Table 2.3 provides several design parameters that describe the Accord PMSM stator and rotor assemblies and the PM volume and mass. The stator slot geometry is more fully described in Fig. 2.5.

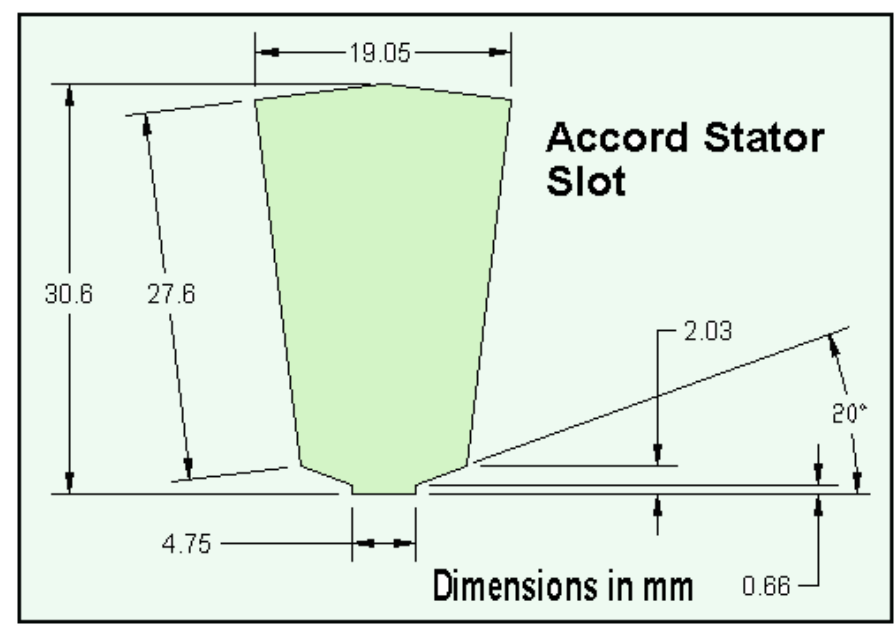

Fig. 2.5. Stator slot geometry. 
Table 2.3. Key design parameters for the Accord PMSM

\begin{tabular}{|c|c|c|}
\hline Parameter & Accord & Comments \\
\hline Stator OD, mm & 315.5 & \\
\hline Stator ID, mm & 232 & \\
\hline Rotor OD, mm & 230 & \\
\hline Rotor ID, mm & 188 & \\
\hline Rotor stack length, mm & 41.2 & Lamination only \\
\hline Stator stack length, mm & 40.1 & Lamination only \\
\hline Air gap, mm & 1 & \\
\hline Lamination thickness, mm & 0.343 & \\
\hline End-turn length, mm & 35 & Approx middle line \\
\hline $\begin{array}{l}\text { End-turn length (phase lead side), } \\
\text { mm }\end{array}$ & 35 & Approx middle line \\
\hline End turn arc extension, mm & $\sim 6.5-10$ & Perpendicular from lamination \\
\hline Stator turns per coil & 52 & \\
\hline Parallel circuit per phase & 8 & \\
\hline Turns in series per phase & 0 & \\
\hline Number of poles & 16 & \\
\hline Number of stator slots & 24 & \\
\hline Number of wires in parallel & 0 & \\
\hline Wire diameter & $1.55 \mathrm{~mm}$ & \\
\hline Slot depth, mm & 30.6 & \\
\hline Slot opening, mm & 4.75 & \\
\hline Slot area, $\mathrm{mm}^{2}$ & 307 & \\
\hline Phase resistance at $21^{\circ} \mathrm{C}$, ohm & 0.0097 & \\
\hline Stator winding mass, kg & 3.01 & \\
\hline Stator core mass, kg & 7.704 & Laminations only \\
\hline Rotor mass, kg & 8.02 & Without bearings \\
\hline Magnet width, mm & 18.45 & Individual magnets (two/pole) \\
\hline Magnet thickness, mm & 4.46 & Individual magnets (two/pole) \\
\hline Magnet length, mm & 40.4 & Individual magnets (two/pole) \\
\hline Magnet Volume, $\mathrm{mm}^{3}$ & 3320 & For a pole, double volumes \\
\hline Magnet mass, g & 25 & For a pole, double masses \\
\hline
\end{tabular}

\subsection{INVERTER SUBSYSTEM}

Honda reports [7] several design features/innovations in the Accord inverter system:

- Vector control

- Precise resolution of the rotor resolver

- Use of a small dc link film capacitor

- Transfer-mode power module (TPM) for improved power, efficiency, and size reduction

- Fine patterning of chips for improved power, efficiency, and size reduction

Figure 2.6 shows the inverter control module (left) and the driver circuit, power electronics assembly, and inverter heat sink (right). These assemblies are mounted behind the rear seat of the Accord in an aircooled casing that also contains the air conditioner inverter, motor/battery electronic-control unit (ECU), $\mathrm{dc} / \mathrm{dc}$ converter, and the neodymium iron boron (NiMH) battery.

Figure 2.7 shows some of the internal components in the inverter casing. The dc link capacitor is well protected inside a steel box. The power electronics driver board is shown in the foreground. In preparing 
for performance testing, it was discovered that the Accord driver board, unlike the Prius driver board, does not incorporate dead-time generation. Instead, Honda incorporated dead-time generation within the inverter control module, with both upper and lower transistor control signals being transmitted to the inverter driver board via $\sim 3 \mathrm{ft}$ conductors. These conductors create a greater opportunity for electromagnetic interference (EMI), yet the overall potential for EMI in the Accord is relatively low due to the lower inverter bus voltage. Since the laboratory performance testing would rely on an ORNL OpalRT controller system and would not make use of the Honda control module, it was necessary to construct an auxiliary dead-time generator circuit.

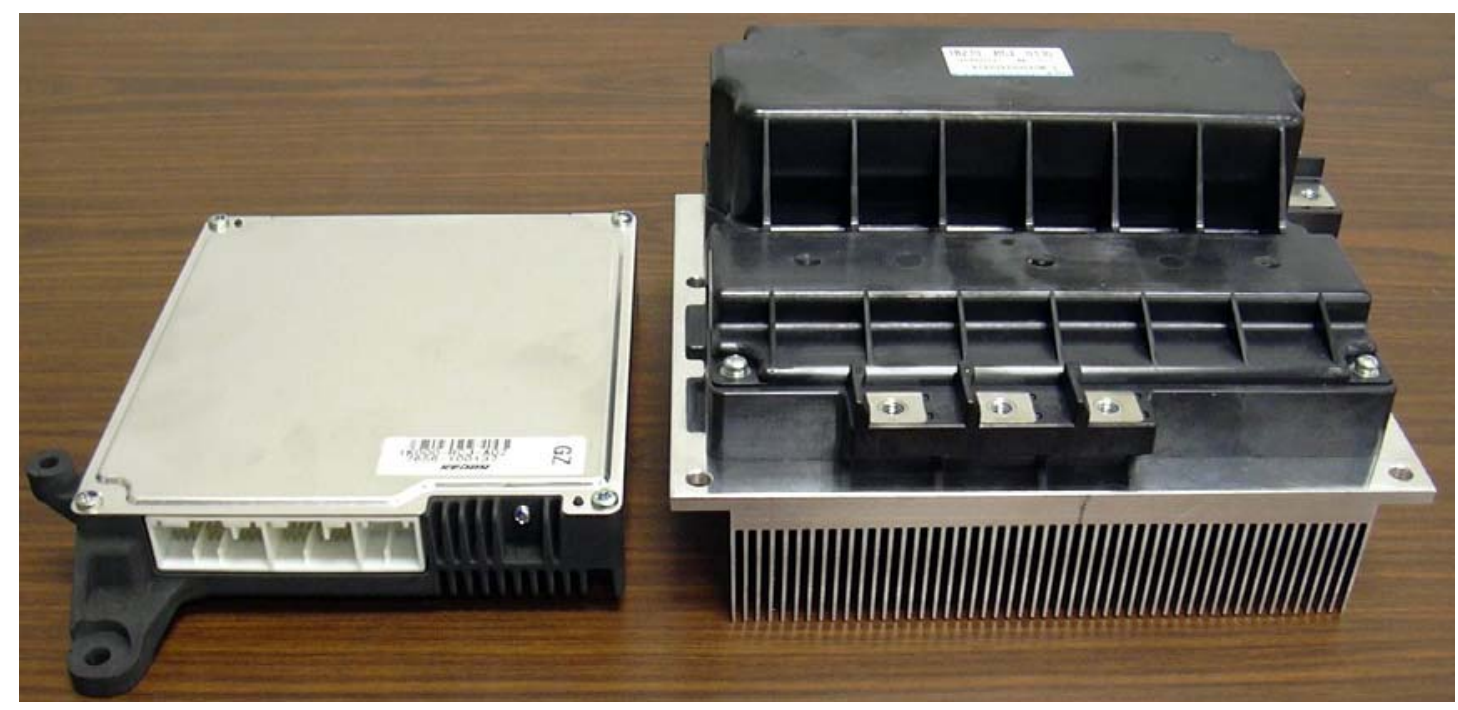

Fig. 2.6. Inverter control module (left) and inverter driver board and heat sink assembly (right).

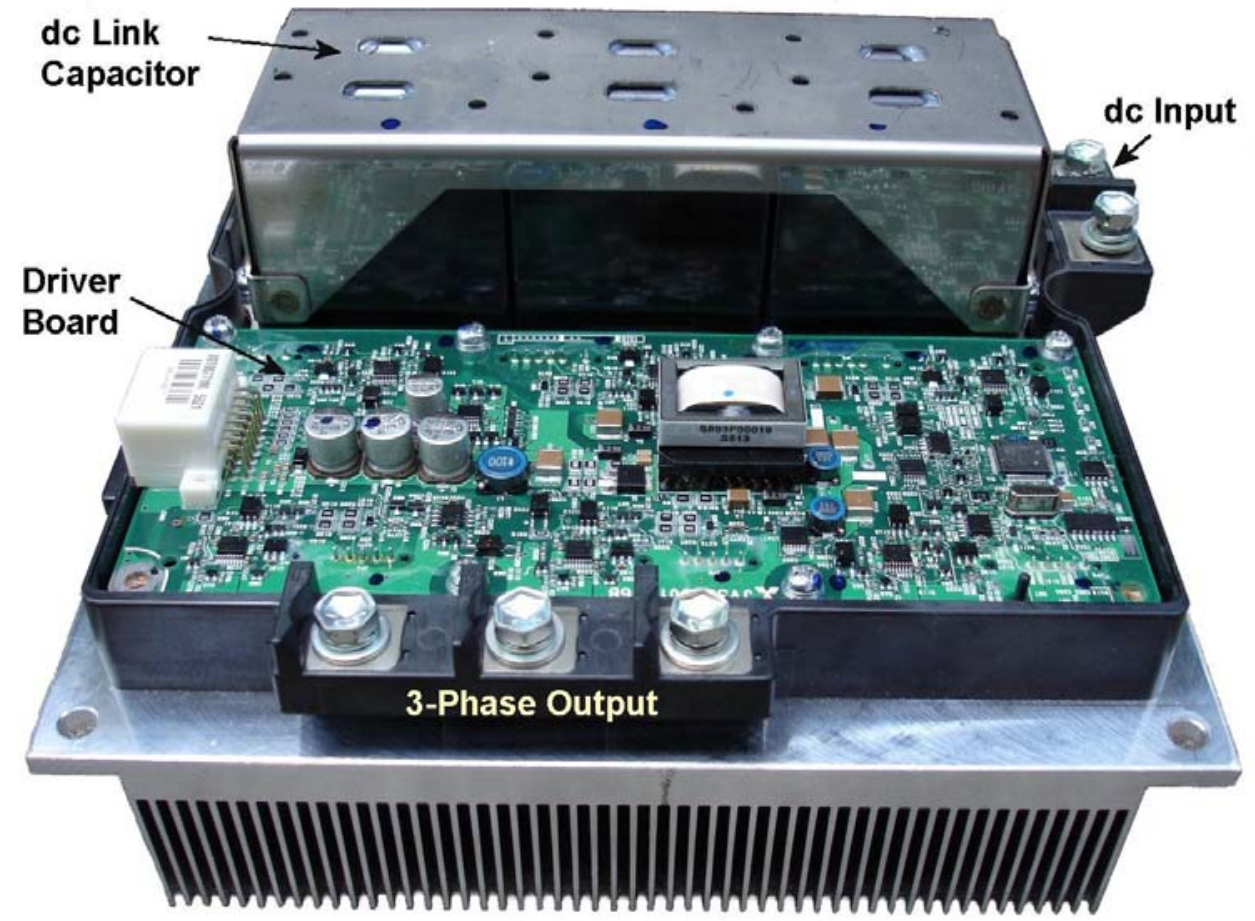

Fig. 2.7. Inverter assembly with protective cover removed. 
Based on an ORNL inspection of the inverter components and assemblies, parameters such as masses, volumes, power density, and specific power were determined. This information is summarized in Table 2.4. Note that the power density and specific power are based on the "peak" or intermittent-duty power rating of the subsystems shown.

Table 2.4. Summary of physical parameters of the Accord inverter

\begin{tabular}{|l|c|c|}
\hline \multicolumn{1}{|c|}{ Component/Parameter } & $\begin{array}{c}\text { Estimated Value for } \\
\text { the Accord }\end{array}$ & $\begin{array}{c}\text { Prius } \\
\text { (comparison of } \\
\text { key parameters) }\end{array}$ \\
\hline Inverter volume, L & 1.61 & \\
\hline Inverter heat-sink volume, L & 3.19 & \\
\hline Inverter board/case volume, L & 0.96 & \\
\hline Inverter total volume, L & 4.15 & 3.45 \\
\hline Peak power density, kW/L & $\mathbf{2 . 8 9}$ & \\
\hline Inverter plus heat-sink mass, kg & 4.49 & \\
\hline Inverter board/case mass, kg & 0.58 & \\
\hline Inverter total mass, kg & 5.07 & 2.6 \\
\hline Peak specific power, $\mathbf{k W / k g}$ & $\mathbf{2 . 3 7}$ & \\
\hline
\end{tabular}

Because of the temperature limitations of the power devices used in the inverter, the Accord vehicle had to be designed to provide a significant level of cool, forced air flow over the heat sink. Peak ambient temperature is more effectively limited by placing the inverter behind the rear seat of the vehicle instead of in the engine compartment (as in the Prius design). The cooling scheme uses a 120W electric blower system and duct work to cool the inverter, battery, and other assemblies. As evident in Fig. 2.8, the blower system components (most, but not all, are shown) require considerably more volume in the back of the passenger compartment than the inverter itself.

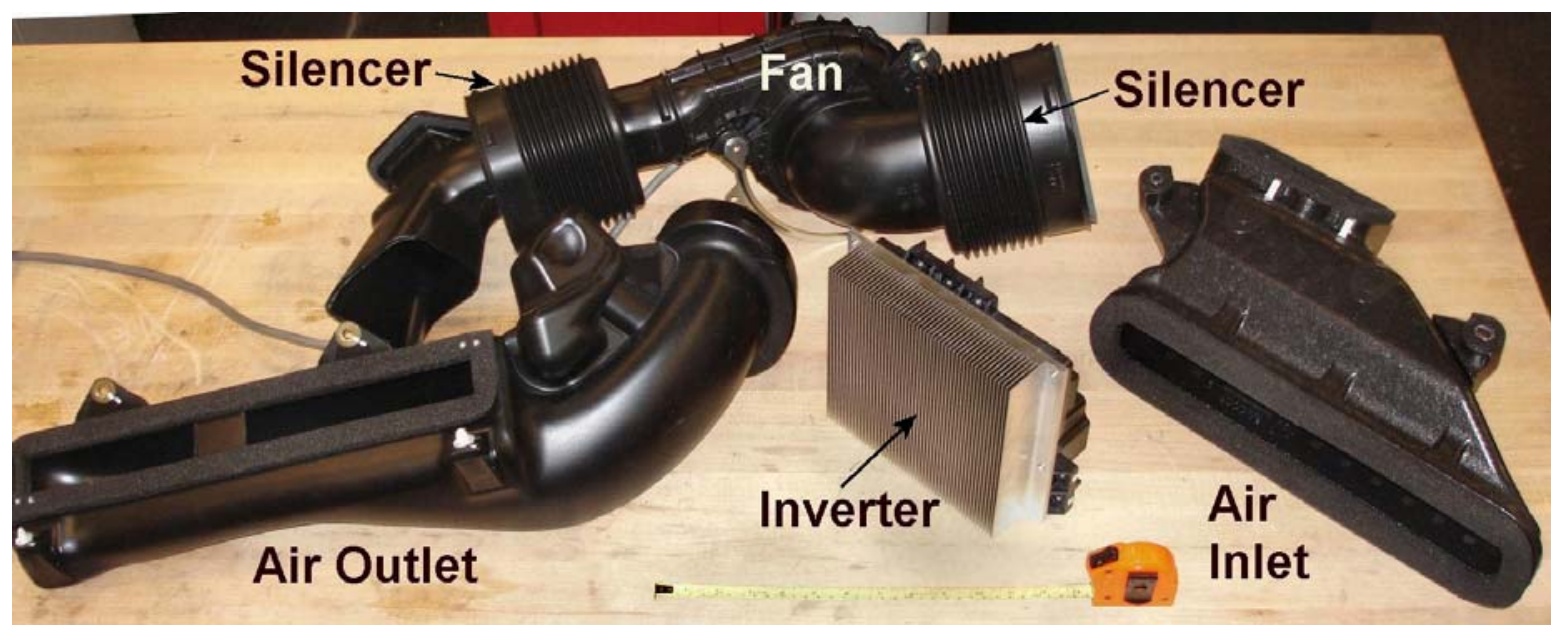

Fig. 2.8. Size comparison of selected blower system components and inverter. 


\section{BENCHMARKING TESTS OF ACCORD PMSM AND INVERTER}

This section describes the Accord subassembly preparation and the back-emf, locked-rotor, performance mapping, and extended duration load tests. With the exception of the back-emf and locked-rotor tests, which did not require inverter operation, each was performed using both the PMSM and inverter subsystems.

\subsection{SUBSYSTEM PREPARATION FOR TESTING}

\subsubsection{Hardware}

The Accord PMSM is designed to be very narrow $(68 \mathrm{~mm})$ to allow it to be inserted between the engine and torque converter. Consequently, the motor was designed without a full casing (ends are missing) and the rotor was designed without a shaft and bearings. In preparation for motor operation in the ORNL laboratory, a shaft was designed and installed in the rotor, and end plates with bearings were designed and installed. The completed, stand-alone motor assembly is shown in Fig. 3.1.
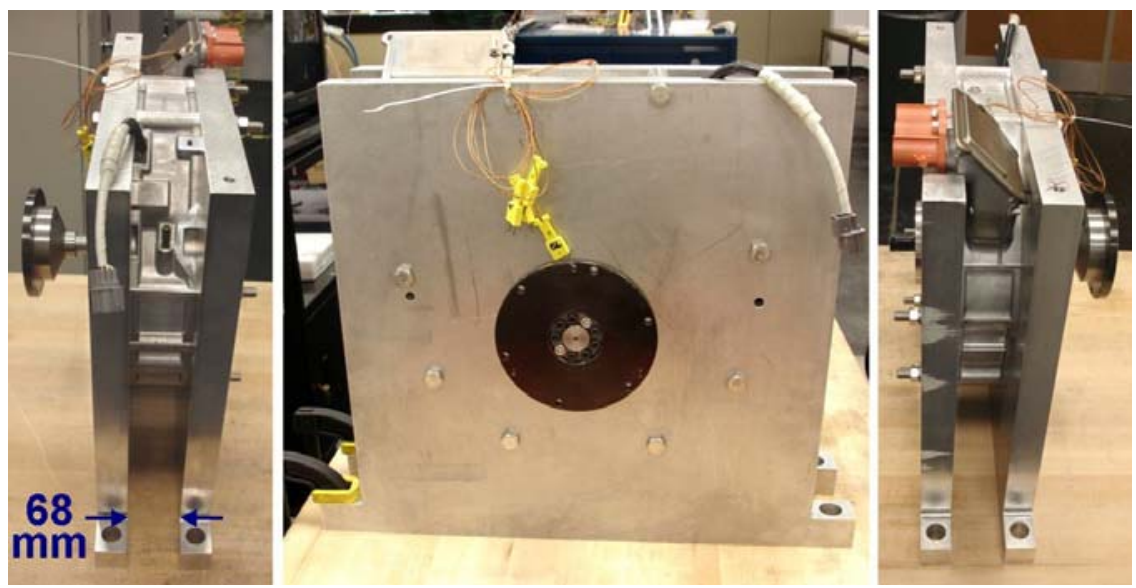

Fig. 3.1. Accord motor with custom-designed end plates and shaft.

Thermocouples (TCs) were installed inside the motor aluminum casing at the top, bottom, left (9 o'clock), and right (3 o'clock) positions. Each was located halfway between the two end plates. Three additional TCs were located in the stator between adjacent windings (see Fig. 3.2) at the 8,12, and 4 o'clock locations.

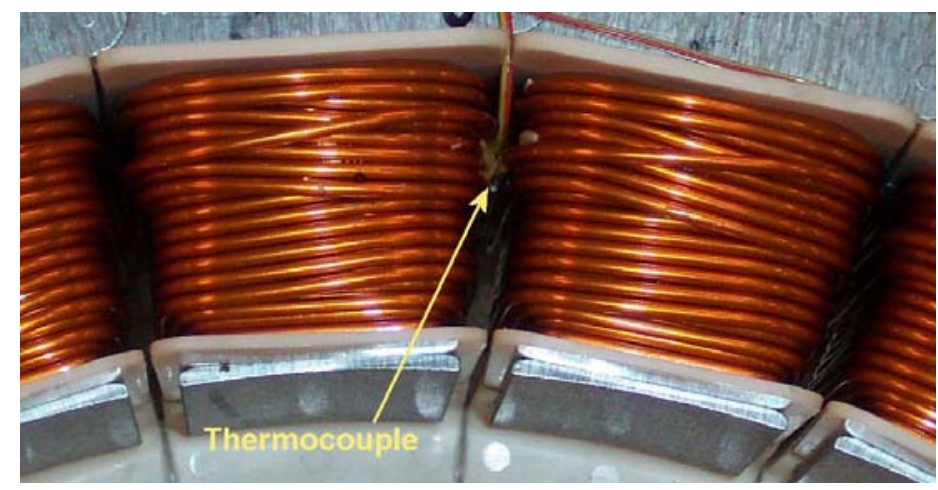

Fig. 3.2. Bonding of a TC between two adjacent stator windings. 
The inverter heat sink was prepared for thermal measurement by the installation of two TCs between fins at the bottom of the slots, as indicated in Fig. 3.3. The inverter circuitry was also prepared by the construction of a dead-time generator circuit. Prior to testing, several switching frequencies and dead times were used while the system efficiencies were monitored to observed the resulting effects. The dead time was set to $4 \mu \mathrm{sec}$ for the duration of the testing.

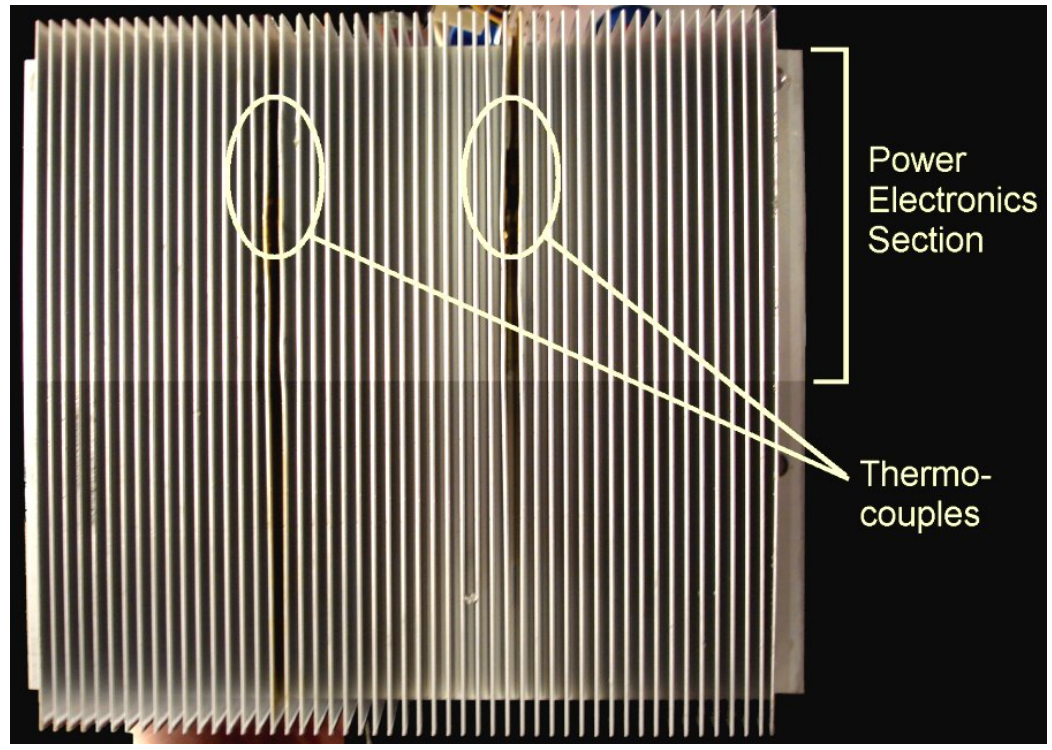

Fig. 3.3. Location of TCs on the inverter heat sink.

The test cell was prepared by the installation of the motor, inverter, power analyzer, current transformers (CTs), and other instrumentation as shown in Fig. 3.4 and Fig. 3.5. The shafts were precision aligned with a laser-based alignment system and the torque cell and other instruments were calibrated to ensure high accuracy in the test data.

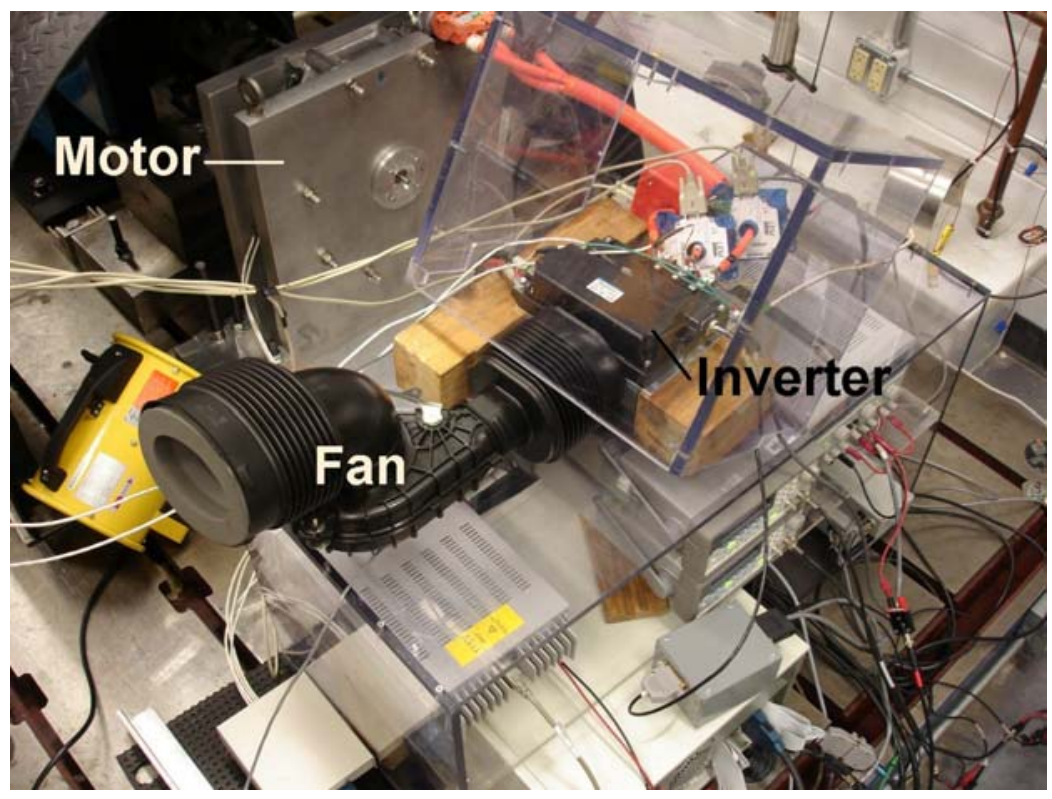

Fig. 3.4. Preparation of test cell for Accord performance testing. 


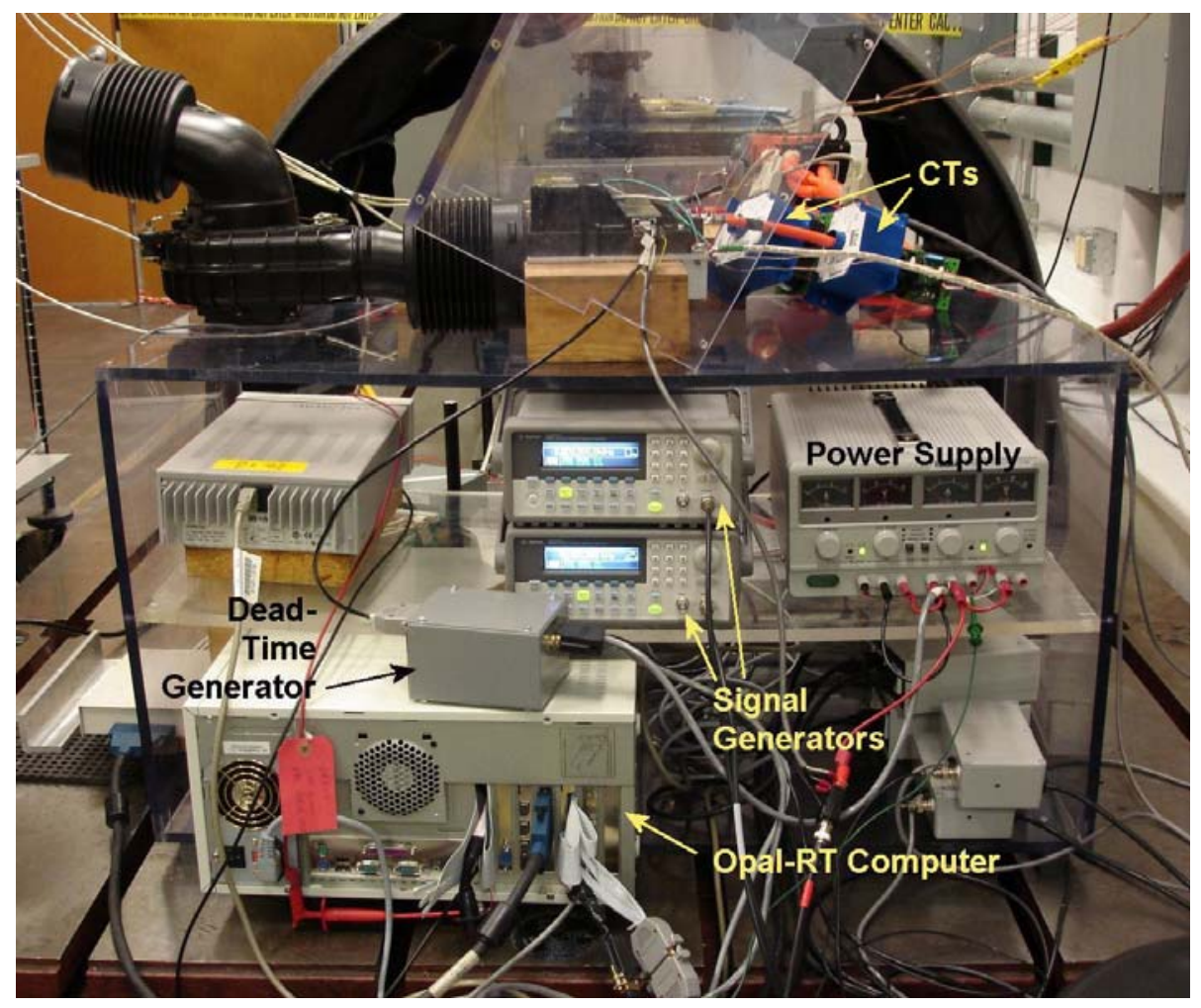

Fig. 3.5. Test cell equipment supporting Accord performance testing.

\subsubsection{Controller}

The IMA system for the 2005 Honda Accord was evaluated for performance characteristics such as peak and continuous torque and power ratings. According to published specifications of the IMA system, the motor is described to have a peak power rating of $12 \mathrm{~kW}$ with a continuous torque of $83 \mathrm{Nm}$, and a peak torque of $136 \mathrm{Nm}$ at $865 \mathrm{rpm}$ [8]. Continuous operation capabilities are greatly affected by the heat transfer characteristics of the motor, which is cooled only through air convection and heat conduction to surrounding engine/transmission masses, without external assistance from a fan or active water/glycol cooling loop.

The IMA system was operated over a broad torque-speed range in order to collect and analyze thermal and electrical data at a multitude of operation points. For each operation point, the system was held in steady state for at least 20 seconds as a minimum of 5 data samples were taken. Additionally, various control conditions, such as field weakening, were adjusted at each test point as the system efficiency was monitored to ensure optimal efficiency.

ORNL's dynamometer test cell and Opal-RT-based speed and current feedback controller were adapted to provide the torque needed at each reference speed. Thus, as the applied torque from the dynamometer was varied manually, the controller regulated the torque producing current appropriately. The current controller consists of two standard proportional-integral (PI) controllers for the direct and quadrature currents, $i_{d}$ and $i_{q}$ respectively. These $d$ - $q$ components are obtained by applying the $d$ - $q$ transformation to the three-phase currents which have a fixed reference. The transformation converts the three-phase currents into two-phase vectors, which have a reference that rotates with the rotor. Therefore, precise rotor position feedback is used during this transformation. 
The steady state torque equation for the salient PM machine is expressed by:

$$
\tau_{L}=n_{p}\left(L_{d}-L_{q}\right) i_{d} i_{q}+n_{p} K i_{q}
$$

where

$n_{p}$ is the number of pole pairs

$L_{d}$ is the $d$-axis inductance

$L_{q}$ is the $q$-axis inductance

$K$ is the back-emf and torque-current factor

The total torque given by Eq. (1) consists of two torque terms, which are reluctance torque and PM torque respectively. PM torque is produced only by the current component along the q-axis. If negative current is applied along the $d$-axis, positive reluctance torque is developed since the difference, $L_{d}-L_{q}$, in the first term is negative and all remaining variables and constants are positive in the motoring region. In theory, there is an infinite amount of $d-q$ current combinations that will satisfy a particular operation condition. There is an optimal $d$-q current combination in which the motor efficiency is maximized for each particular torque. It is difficult to determine the optimal current trajectories for the entire torque-speed range, as complex factors such as effects of saturation and harmonics must be considered. Therefore, the data acquisition system was used to monitor the system efficiency as various $d$ - $q$ current combinations were explored for each data point. After the optimal current angle and magnitude is defined for several operation points, it becomes easier to predict the optimal condition for nearby operation points.

Additional details pertaining to the controller are provided in the final report on the Prius benchmarking [3].

\subsection{BACK-EMF TEST}

The non-energized Accord PMSM was spun at various speeds over its full design range to obtain backemf data. The shaft speed and back-emf data (line-to-neutral rms averaged for the three phases) is plotted in Fig. 3.6. The full set of data, including individual line-to-neutral voltages, is listed in Table 3.1. This test was repeated after the performance/efficiency mapping test to verify that no magnetic strength was lost in the rotor during performance tests or extended periods of high-temperature testing. As expected, there were no significant differences in the data obtained from the second back-emf test.

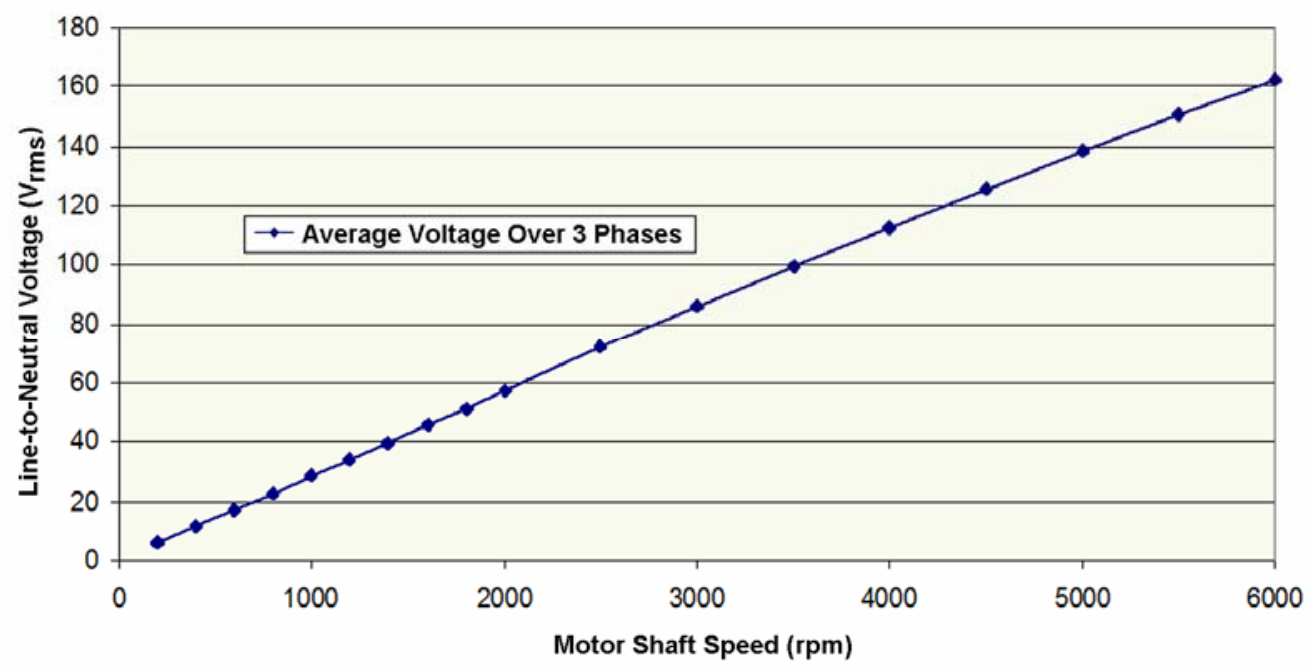

Fig. 3.6. Average line-to-neutral back-emf vs. shaft speed (2005 Accord motor). 
Table 3.1. Back-emf vs. shaft speed data (2005 Accord motor)

\begin{tabular}{|c|c|c|c|c|}
\hline \multirow{2}{*}{$\begin{array}{c}\text { Speed } \\
\text { (rpm) }\end{array}$} & \multicolumn{4}{|c|}{ Back-emf (line-to-neutral rms voltages) } \\
\cline { 2 - 5 } & Va & Vb & Vc & Average \\
\hline 200 & 6 & 5.92 & 5.62 & 5.85 \\
\hline 400 & 11.11 & 11.64 & 11.63 & 11.46 \\
\hline 600 & 17.44 & 17.19 & 16.77 & 17.13 \\
\hline 800 & 22.51 & 22.72 & 23.27 & 22.83 \\
\hline 1000 & 28.79 & 28.14 & 28.61 & 28.51 \\
\hline 1200 & 34.44 & 33.94 & 34.12 & 34.17 \\
\hline 1400 & 39.83 & 39.87 & 39.88 & 39.86 \\
\hline 1600 & 45.59 & 45.51 & 45.56 & 45.55 \\
\hline 1800 & 51.23 & 50.9 & 51.62 & 51.25 \\
\hline 2000 & 57.39 & 56.93 & 56.97 & 57.10 \\
\hline 2500 & 71.77 & 71.48 & 72.59 & 71.95 \\
\hline 3000 & 85.87 & 85.53 & 86.25 & 85.88 \\
\hline 3500 & 99.95 & 99.08 & 99.89 & 99.64 \\
\hline 4000 & 112.9 & 111.7 & 113.3 & 112.6 \\
\hline 4500 & 125.3 & 124.7 & 126.3 & 125.4 \\
\hline 5000 & 137.9 & 137.7 & 139.7 & 138.4 \\
\hline 5500 & 150.2 & 150.0 & 151.7 & 150.6 \\
\hline 6000 & 162.0 & 161.1 & 163.6 & 162.2 \\
\hline
\end{tabular}

\subsection{LOCKED ROTOR TEST}

A series of locked rotor tests were performed to determine the torque-producing behavior of the PMSM motor. A motorized mechanical-gear mechanism was used to precisely position and lock the rotor based on readings from the absolute position sensor in the motor.

A motor-driven gear mechanism was used to rotate the motor incrementally every five electrical degrees, and the fixture remained rigidly locked each time a set level of dc current was applied. Torque values were obtained from an in-line shaft torque sensor when the motor windings were energized. The resulting data was used to produce torque- vs.-shaft-angle plots, which are shown in Fig. 3.7 for various current levels over a full electrical cycle. The levels of torque that were produced reflect the absolute maximum torque obtainable from the motor for each current (magnetic torque and reluctance torque). In contrast to an operating motor, there are no eddy current core losses, losses due to windage, and bearing friction.

The nine peak-torque values for the nine corresponding current levels are plotted in Fig. 3.8 and the numeric values are shown in Table 3.2. Magnetic flux saturation in the motor becomes significant above $\sim 175 \mathrm{~A} .{ }^{1}$ This series of tests was effective in characterizing the starting torque capability of the 2005 Accord PMSM.

\footnotetext{
${ }^{1}$ In comparison, the saturation became significant in the Prius at $115 \mathrm{~A}$.
} 


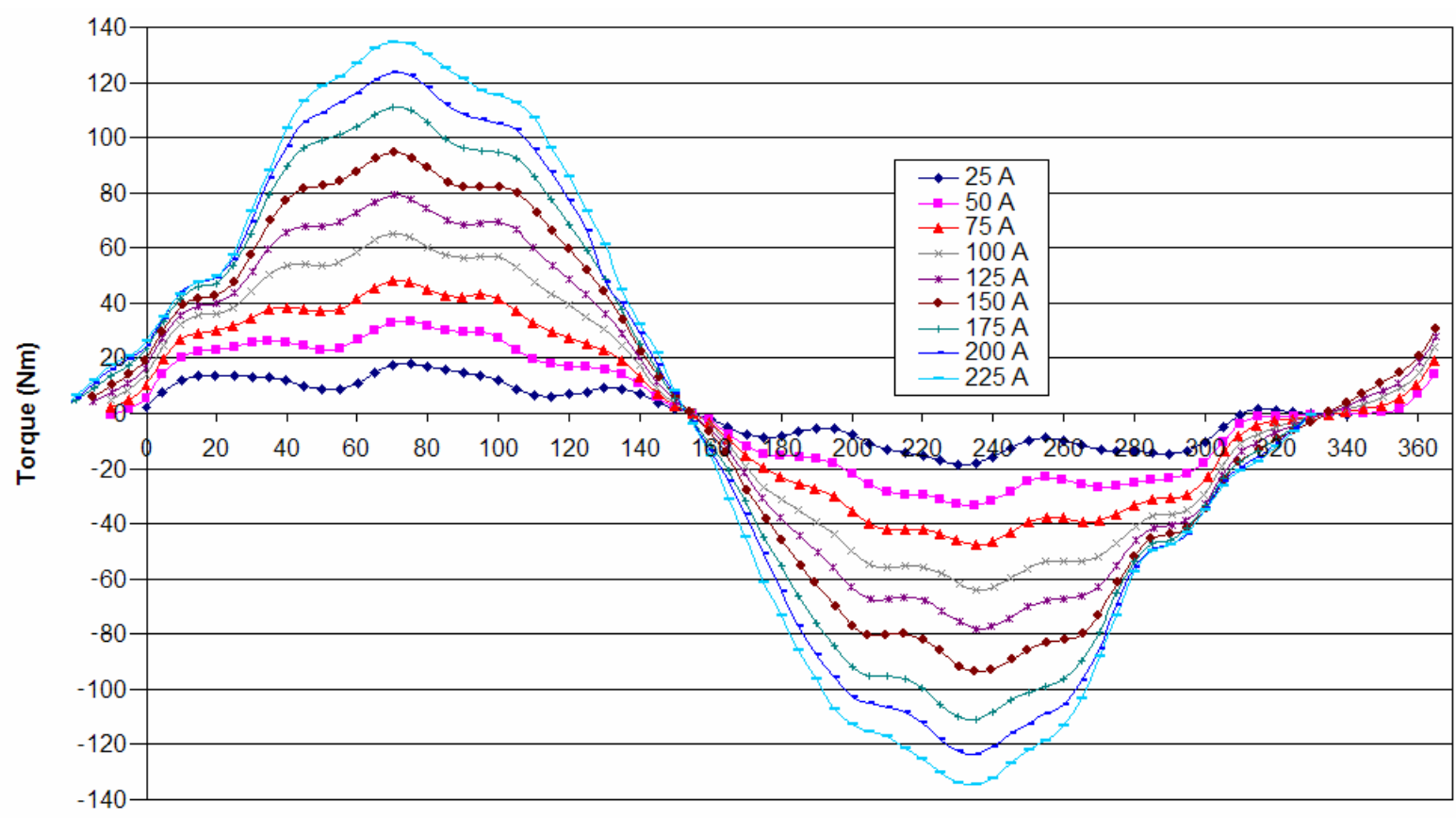

Electrical Position (Degrees)

Fig. 3.7. Magnetic torque vs. electrical position at varying levels of stator current.

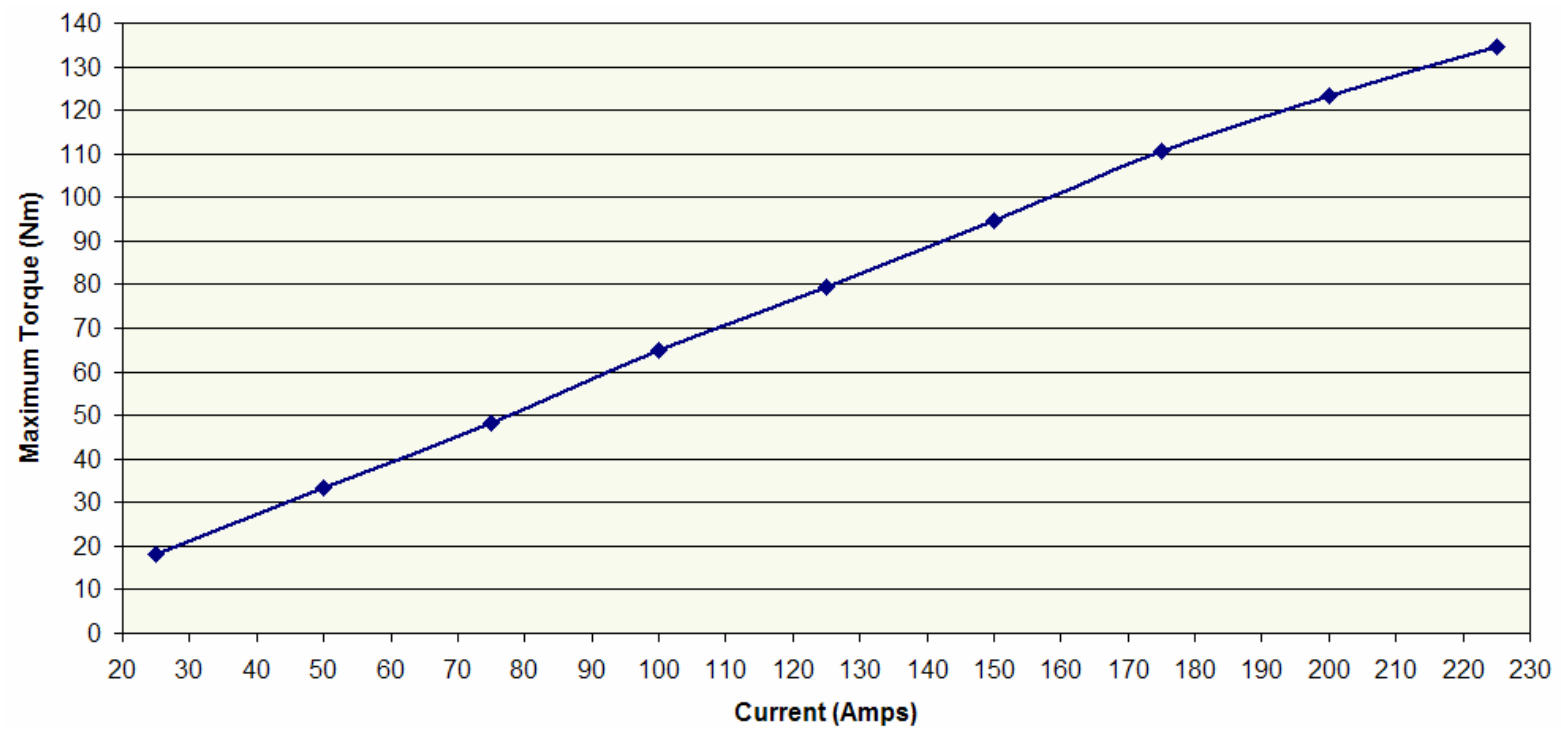

Fig. 3.8. Maximum magnetic torque vs. stator current (locked-rotor test). 
Table 3.2. Maximum torque vs. stator current

\begin{tabular}{|c|c|}
\hline Current & Max Torque \\
\hline 25 & 18.3 \\
\hline 50 & 33.3 \\
\hline 75 & 48.1 \\
\hline 100 & 64.9 \\
\hline 125 & 79.4 \\
\hline 150 & 94.5 \\
\hline 175 & 111 \\
\hline 200 & 123 \\
\hline 225 & 135 \\
\hline
\end{tabular}

\subsection{PERFORMANCE MAPPING TEST}

This section provides Accord subsystem performance-mapping data including efficiency contour mapping plots. The motor efficiency contour map, ranging from 250-5000 rpm and with shaft loading levels up to $140 \mathrm{Nm}$, is presented in Fig. 3.9. It shows motor efficiencies peaking at 94-95\% in certain combinations of the 500-3200 rpm speed range and moderate torque levels (20-75 Nm). The lowest efficiencies are evident at several fringe regions of the contour, especially at low-speed, high-torque conditions, and loads below $8 \mathrm{Nm}$ at all speeds. Since one of the primary applications of the motor is to assist the engine in accelerating the vehicle from a stop, operation in the low-speed/high-torque region is common for brief periods of time.

Figure 3.9 and subsequent efficiency maps, show the plotting of two iso-power lines at $12 \mathrm{~kW}$ and $14 \mathrm{~kW}$. Although the motor is rated at $12 \mathrm{~kW}$, adherence to stator heating limits did not present any obstacle to operating at $14 \mathrm{~kW}$ and $15 \mathrm{~kW}$ for 20-30 seconds to make adjustments and obtain several sets of data. Thus, the $12 \mathrm{~kW}$ rating for the motor appears to be conservative for the short-duration of maximum power that is required of it in the Accord HEV system. This is based on both inverter and motor temperatures, with the exclusion of the rotor PM temperatures which were not measured. 


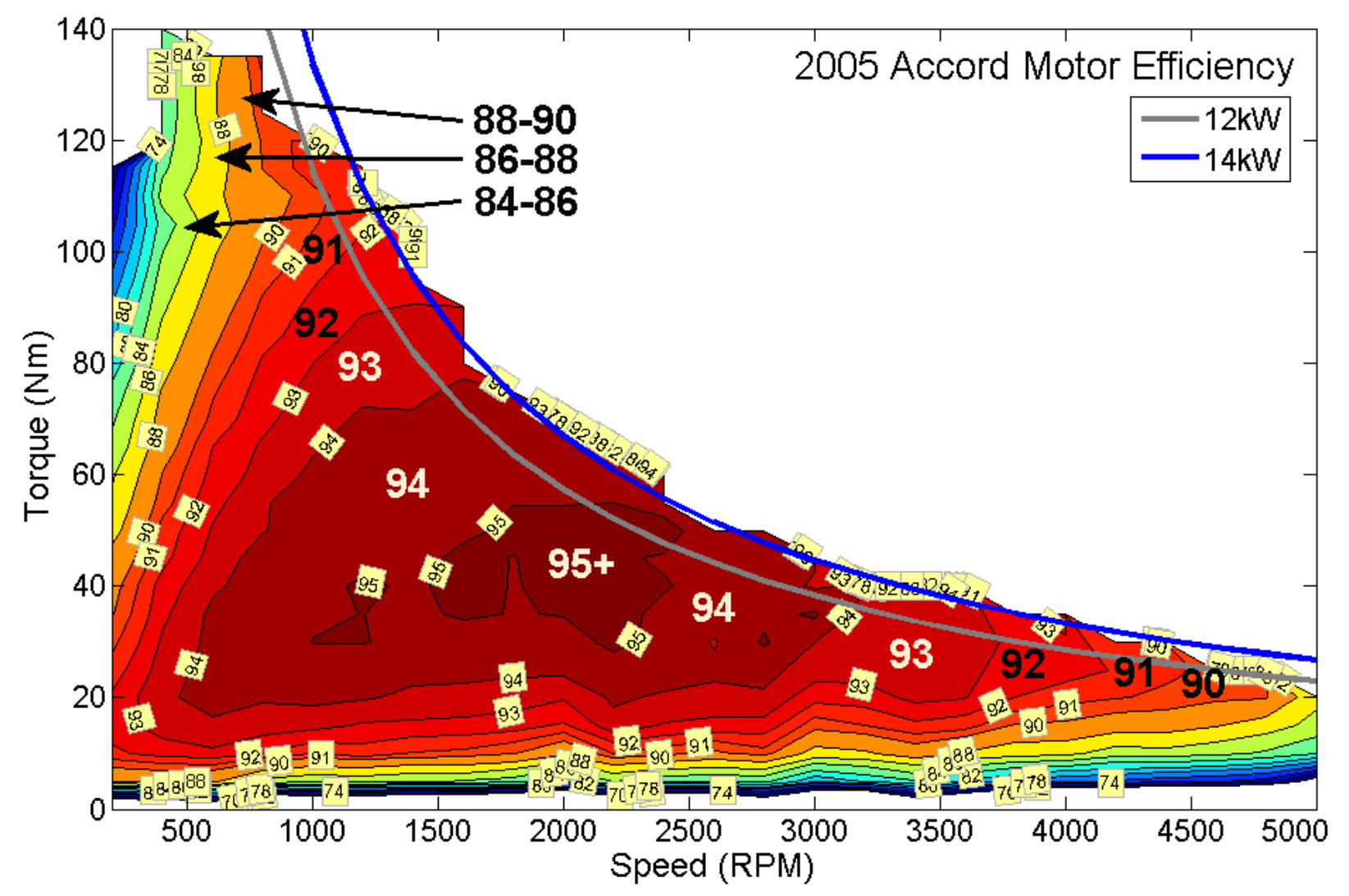

Fig. 3.9. 2005 Accord motor efficiency contour map.

As evident in Fig. 3.9, motor data at speeds greater than 5000 rpm are not shown. During testing, it was discovered that motor operation in the laboratory was not stable above $5000 \mathrm{rpm}$. This is likely due to a voltage limit associated with a dc bus voltage of $144 \mathrm{~V}$. Since it would have required considerable resources to verify this supposition and because the 5000-6000 rpm range has little significance in the normal operation of the Accord vehicle, the tests were terminated at $5000 \mathrm{rpm}$.

The inverter efficiency contour map, ranging from 250-5000 rpm, is presented in Fig. 3.10. It shows a large area of high 96-97\% efficiencies above 1300 rpm. At lower motor speeds, inverter efficiency drops down into the 80-90\% efficiency range. Clearly, motor shaft speed or fundamental electrical frequency (not load levels) generally determine inverter efficiency at speeds below 2000 rpm; however, above 2000 rpm, it is primarily the load or current levels that determine efficiency. 


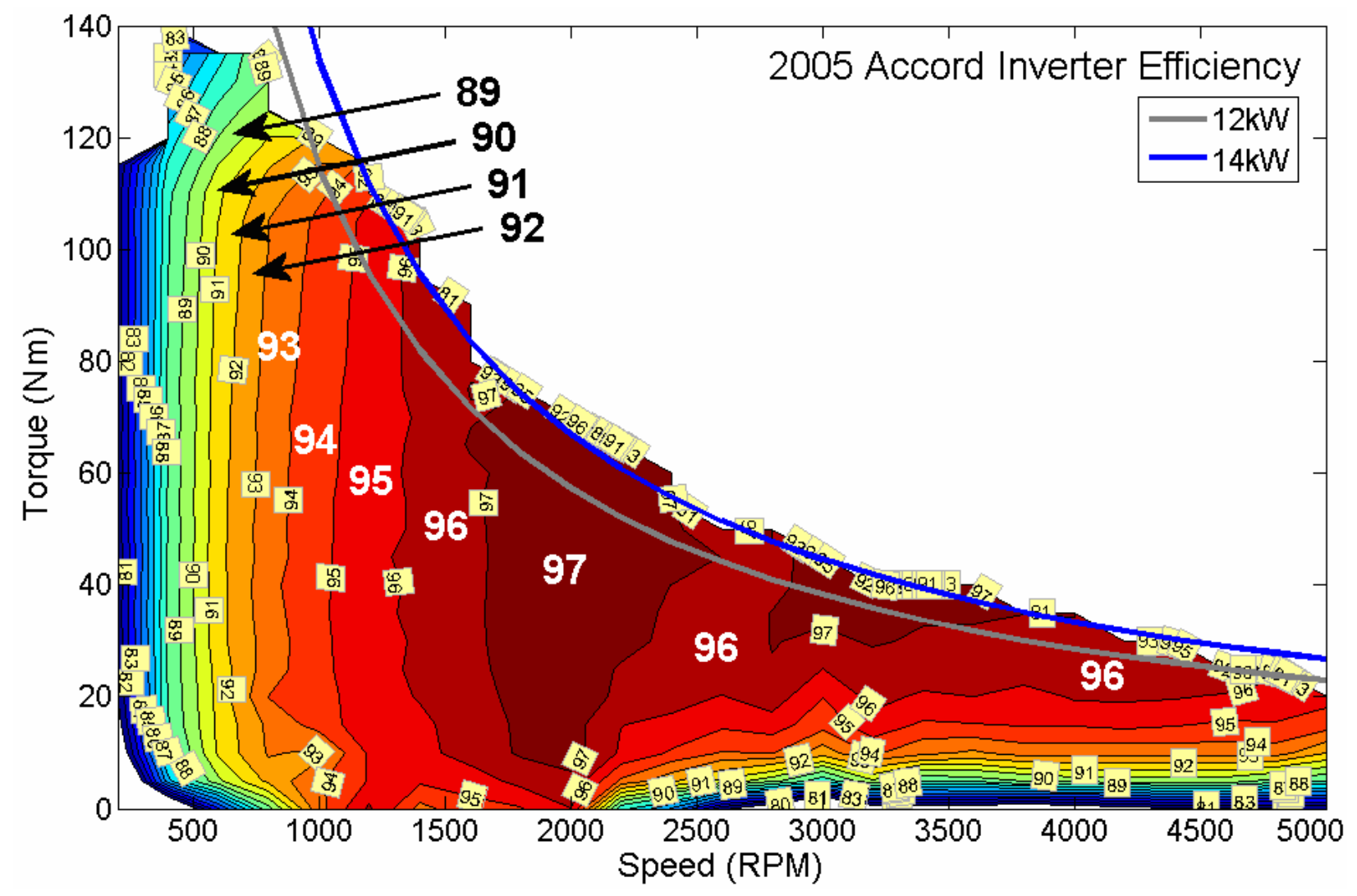

Fig. 3.10. 2005 Accord inverter efficiency contour map.

The most significant efficiency mapping for the Accord HEV system is for the combined motor and inverter performance. This is shown in Fig. 3.11 for efficiencies of $70 \%$ and higher $(<70 \%$ excluded for clarity). The highest efficiency was $92 \%$, which is seen in many combinations of the 1500-2500 rpm speed range and moderate levels of shaft loadings (30-70 Nm). The largest regions of low efficiency are seen at low speed with high loading and high speed with low loading. In terms of vehicle energy management, the most significant region of low efficiency is at low speed, high loading since a primary application of the motor is to assist the engine in accelerating the vehicle from a stop. In this region, efficiencies were recorded as low as $60 \%$ (not shown) during testing; however, the dynamometer system was not able to fully load the motor at speeds below $250 \mathrm{rpm}$, where efficiencies are expected to be even lower.

Appendix A presents comparisons of the Accord and Prius Efficiency contour maps for the motor, inverter, and motor plus inverter. The Accord-Prius comparisons show how, in terms of efficiency, the Accord motor excels, the Prius inverter excels, and the combined systems are generally about the same over much of the speed and shaft-load domain.

Following the tests, ORNL learned from Argonne National Laboratory (ANL) vehicle test data that the inverter operates with a switching frequency of $12 \mathrm{kHz}$ and a dead time of $6.5 \mu$ s instead of $10 \mathrm{kHz}$ and $4 \mu$ s used in the tests. ORNL then ran some additional tests to determine if efficiency data would change if these two vehicle parameters use used. No significant change was seen in the data. 


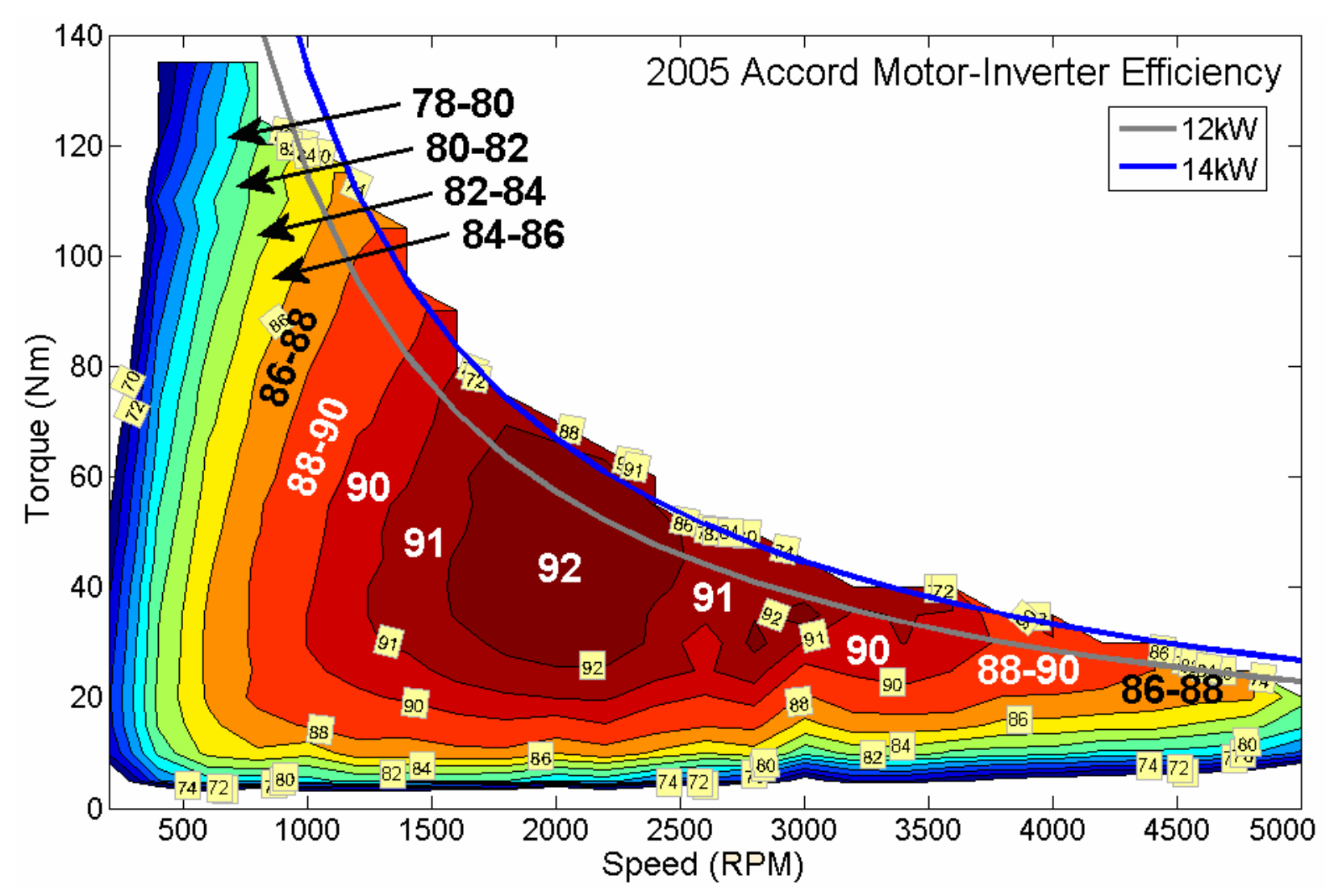

Fig. 3.11. 2005 Accord motor-plus-inverter efficiency contour map.

\subsection{EXTENDED-DURATION LOAD TEST}

Although not part of the original scope of work, a brief effort was devoted to performing an extendedduration load test to assess the potential of the Accord motor to operate for extended periods of time without stator winding temperatures becoming excessive. The more conventional "continuous-duty test" cannot be well defined for motors that operate for only seconds, primarily during accelerations, and for a passively cooled motor such as used in the Accord that tends to heat up gradually even after several minutes of operation.

Figure 3.12 shows the stator winding temperature and torque plotted over a 52 minute period. The two temperature plots are based on two TCs bonded between adjacent stator coils/bobbins. The specific goals of the test were to operate (1) at $\sim 170^{\circ} \mathrm{C}$ for several minutes since it is just below the $180^{\circ} \mathrm{C}$ limit for Class $\mathrm{H}$ insulation for a standard 20,000-hr life, and (2) at $200^{\circ} \mathrm{C}$ to reflect an elevated temperature for Class $\mathrm{H}$ insulation that may be acceptable for a 5000 -hr life. ${ }^{2}$ For $170^{\circ} \mathrm{C}$ and $200^{\circ} \mathrm{C}$, the corresponding shaft loading torque values at the base speed of $840 \mathrm{rpm}$ are $65 \mathrm{Nm}(5.7 \mathrm{~kW})$ and $72 \mathrm{Nm}(6.3 \mathrm{~kW})$, respectively. In these two cases, the durations of time for which these results are valid are $\sim 10 \mathrm{~m}$ and $\sim 4$ m, respectively.

\footnotetext{
${ }^{2}$ This is conservative in that it is well beyond the number of hours in a 15 -year period during which the motor is likely to be operated at temperatures above $150^{\circ} \mathrm{C}$.
} 


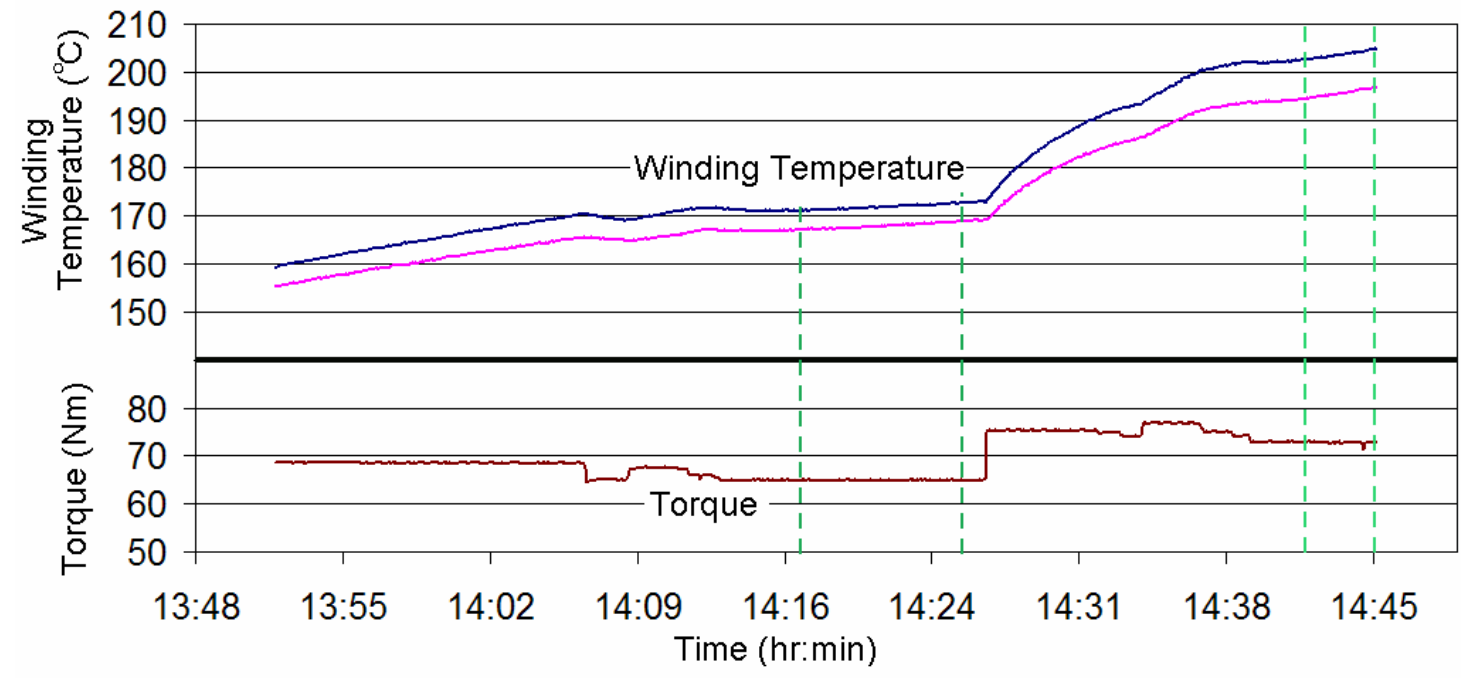

Fig. 3.12. Stator winding temperature and torque vs. time. 


\section{SUMMARY AND RECOMMENDATIONS}

The Accord HEV subsystem assemblies were physically evaluated and comprehensively tested in the laboratory to fully characterize their performance. The laboratory evaluations included back-emf, locked rotor, efficiency mapping, and extended-duration load tests. Overall, the Accord motor and inverter performed quite well and the tests were completed without any unforeseen complications/delays.

Although the Accord HEV system does not have the higher power capability and power density of the Prius, many attractive and/or unique features are evident in its design:

1. Narrow-profile (68 mm) motor design

2. A phased introduction of hybrid technology in a preexisting vehicle model

3. Motor uses no-cost, passive cooling (as does Toyota's rear-axle, air-cooled drive in the Highlander)

4. The inverter and battery are air cooled (although the blower system is physically bulky)

5. Innovative location of inverter $8 \mathrm{ft}$ from motor

a. Avoids harsh engine compartment environment

b. Shares enclosure with HV battery

c. Ten-foot-long, three-phase bus cable is fully shielded to minimize emissions/EMI

6. Use of boost converter is avoided despite a lower-voltage battery than used in the Prius (feasible at the Accord's lower power rating)

Table 4.1 summarizes the key subsystem parameters for the Accord and Prius. The table makes evident the substantially higher motor peak power density and specific power for the Prius. For the same two parameters, the Accord-Prius differences in the inverters are much smaller. This reduced advantage in the inverter is due in part to the fact that the higher-powered Prius inverter also contains a boost converter with a $2.6 \mathrm{~kg}$ inductor, a $0.7 \mathrm{~kg}$ power module, and the additional aluminum to enclose them $(4.2 \mathrm{~kg}$ estimated total). The converter volume is estimated to be $4.7 \mathrm{~L}$.

Table 4.1. Comparison of key subsystem parameters for the Accord and Prius

\begin{tabular}{|l|c|c|}
\hline \multicolumn{1}{|c|}{ Subsystem Parameter } & $\begin{array}{c}\text { Estimated Values } \\
\text { for the Accord }\end{array}$ & $\begin{array}{c}\text { Estimated Values } \\
\text { for the Prius }\end{array}$ \\
\hline Inverter/Motor Peak Power Rating, kW & 12 & 50 \\
\hline Motor Volume, L & 7.9 & 15.4 \\
\hline Motor Mass, kg & 22.6 & 45 \\
\hline Motor Peak Power Density, kW/L & 1.5 & 3.25 \\
\hline Motor Peak Specific Power, kW/kg & 0.53 & 1.1 \\
\hline Inverter Volume, L & 4.15 & $14.5^{1}$ \\
\hline Inverter Mass, kg & 5.07 & $19.4^{1}$ \\
\hline Inverter Peak Power Density, kW/L & 2.89 & $3.5^{1}$ \\
\hline Inverter Peak Specific Power, kW/kg & 2.37 & $2.6^{1}$ \\
\hline
\end{tabular}

${ }^{1}$ Includes the buck/boost converter (see text).

The summary of performance data, such as the efficiency mapping, is already presented in a concise manner in Sect. 3 and will therefore not be duplicated in this summary section.

Now that the ORNL benchmarking project has completed testing on the Prius and Accord HEV subsystems, there are several general observations that can be made regarding the testing performed on each: 
1. The Prius PMSM and inverter perform well although with some difficult challenges [3]

a. PMSM has thermal design weaknesses as $50 \mathrm{~kW}$ peak power is approached (maximum run time must be limited to a several seconds)

b. Additional cooling measures were required to complete testing

c. EMI levels are high in the laboratory's open-wiring configuration, complicating control and data acquisition

2. Accord PMSM/inverter system

a. Power specifications may be conservative relative to the Prius (given similar operating times)

b. The subsystems handle maximum torque/current levels well without additional cooling measures

c. The low inverter dc bus voltage exhibits lower levels of EMI and is therefore more easily controlled/operated

d. Lower potential for EMI and lower peak power levels enable the HEV design to use a remote location of the inverter with long inverter-to-motor, three-phase power cables

There is no standard for establishing power rating specifications for motors designed for low-duty-cycle applications such as the hybrid Accord and Prius motors. The Prius PMSM may be able to sustain a peak power rating of $50 \mathrm{~kW}$ for no more than 10 or 15 seconds (as an example); however, the Accord PMSM, if given the same severe time limitation, may have a peak power rating in the range of $18-20 \mathrm{~kW}$ instead of the commonly published $12 \mathrm{~kW}$ peak power specification. This highlights a very important reason for performing benchmarking tests on HEV subsystems - current technology must be verified objectively under consistent operating parameters before the results are used by the FCVT program and researchers.

The benchmarking of the Accord has been of high value in objectively quantifying volume, mass, power, power density, and specific power parameters for this innovative HEV system. This information is needed by the FCVT program to assess progress towards program targets and to refine the direction of the program. Furthermore, the project has thoroughly documented the performance of the subsystems in terms of power and efficiency. This information, in combination with detailed design data, can be used by researchers to improve/verify analytical models.

As a next step in the benchmarking of different technologies, it would be of high value to the FCVT program and researchers to begin a full assessment of a selected high-speed motor/inverter system. This should be performed in FY2007 and focus on either the Toyota Highlander (12,500 rpm maximum speed) or the Lexus LX 400h (12,400 rpm maximum speed). 


\section{REFERENCES}

1. Source: http://www.eere.energy.gov/vehiclesandfuels/technologies/systems/index.shtml.

2. J. S. Hsu, S. C. Nelson, et al., Report on Toyota Prius Motor Thermal Management, ORNL/TM2005/33, UT-Battelle, LLC, Oak Ridge National Laboratory, Oak Ridge, Tennessee, February 2005.

3. R. H. Staunton, C. W. Ayers, J. Chiasson, T. A. Burress, and L. D. Marlino, Evaluation of 2004 Toyota Prius Hybrid Electric Drive System, ORNL/TM-2006-423, UT-Battelle, LLC, Oak Ridge National Laboratory, Oak Ridge, Tennessee, May 16, 2006.

4. Source: http://www.caranddriver.com/roadtests/8779/honda-accord-hybrid-page4.html.

5. Source:

http://corporate.honda.com/america/government_relations/article.aspx?id=Press_Releases/Press_Gov t $0080 . h t m$

6. Source: http://www.newsday.com/news/columnists/nysstom054728367may05,0,3819561.column?page=2\&coll=ny-rightrail-columnist

7. N. Higuchi (assistant chief engineer for Honda), Honda Accord Hybrid, presented at the SAE Hybrid Vehicle Technologies Symposium-Today and Tomorrow, Costa Mesa, California, February 9-10, 2005.

8. 2005 Accord Hybrid, Service Manual, P/N 61SDR00, Honda Motor Company, 2004. 


\section{APPENDIX A COMPARISONS OF ACCORD AND PRIUS EFFICIENCY MAPS}

Figures A.1, A.2, and A.3 show comparisons of the Accord and Prius efficiency contour maps for the motor, inverter, and motor plus inverter, respectively. In each case, the bottom plot is for the Prius and it shows comments pertaining to how the Prius efficiency compares to the Accord efficiency for the designated area of the map. These comments are "broad-brush" comparisons and should not be taken in a precise, mathematic sense. For instance, very narrow contour regions of the map may be disregarded in the interest of placing emphasis on the larger, more significant areas.

The most important conclusion to be drawn from these figures is the fact that, in terms of efficiency, the Prius inverter excels, the Accord motor excels (except in the high-speed, low-torque region), and the combined HEV system efficiency is essentially the same except for at the low-speed ( $<1000 \mathrm{rpm})$, hightorque region $^{3}$ where the Accord efficiency excels and the high-speed range where the Prius excels.

\footnotetext{
${ }^{3}$ Expressions such as "low-speed, high torque" for the Accord and Prius systems simply refer to corresponding areas or domains in the speed-load maps, even though the actual torque values may be quite different.
} 

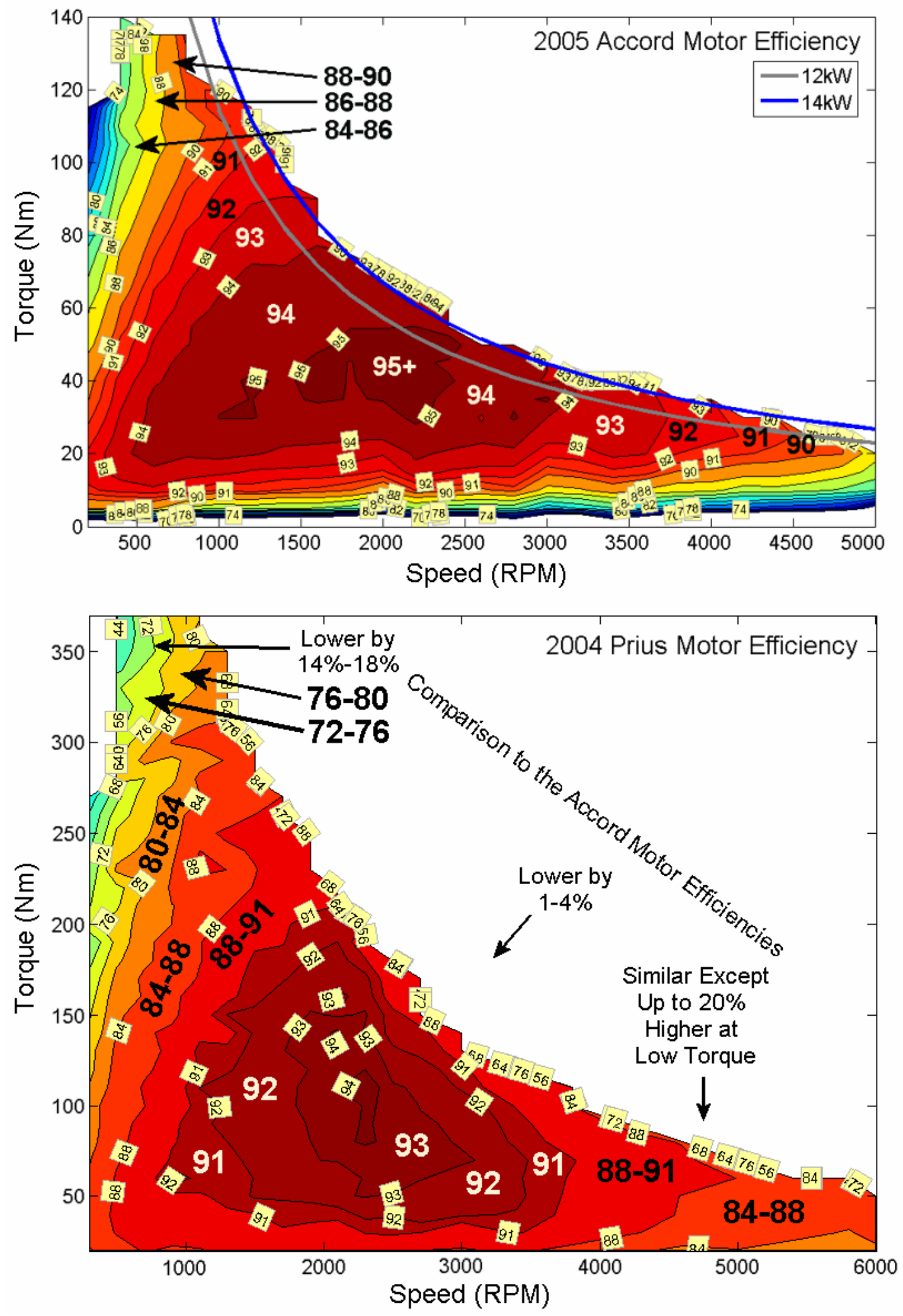

Fig. A.1. Comparison of Accord and Prius motor efficiency contour maps. 

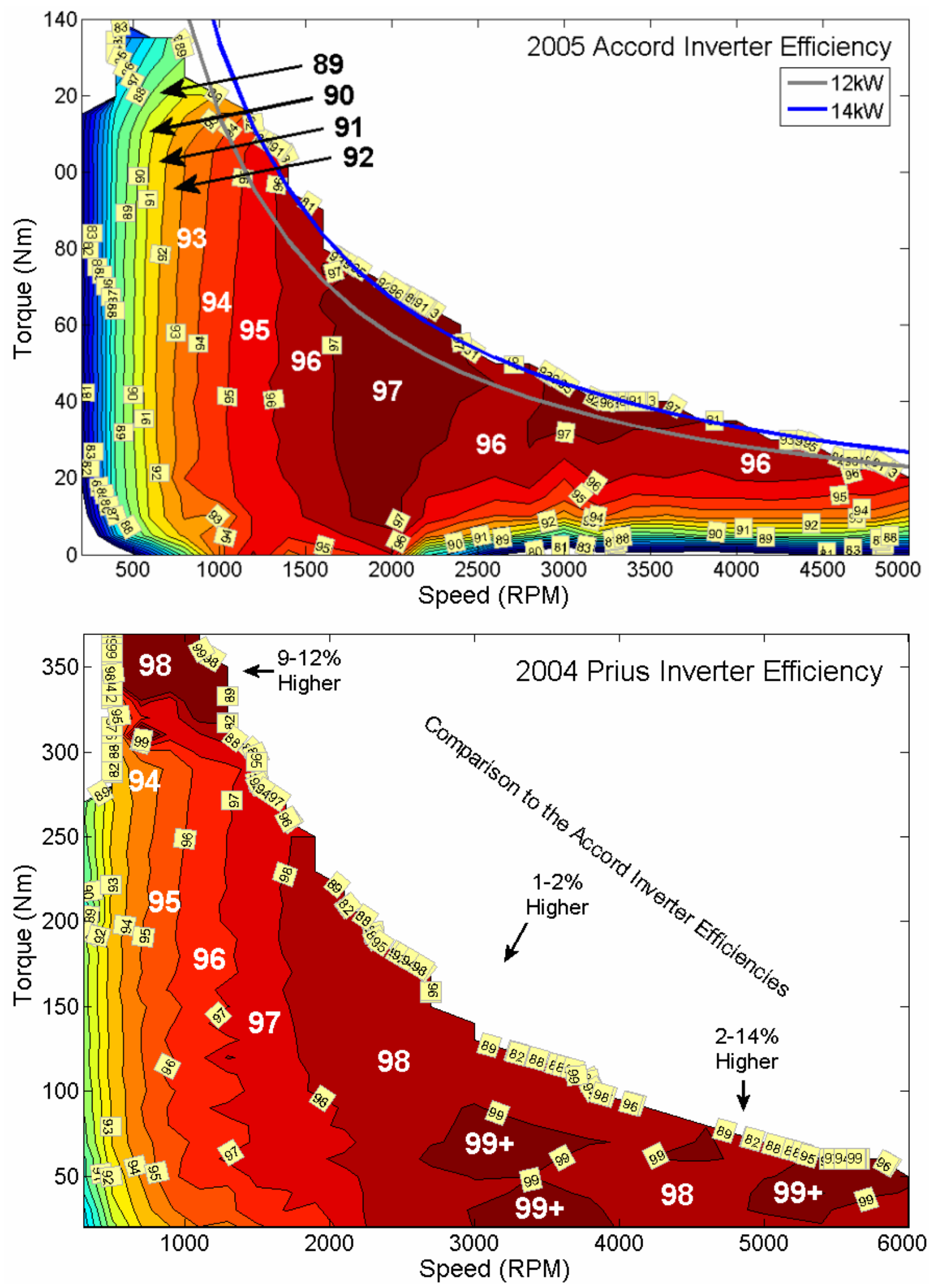

Fig. A.2. Comparison of Accord and Prius inverter efficiency contour maps. 

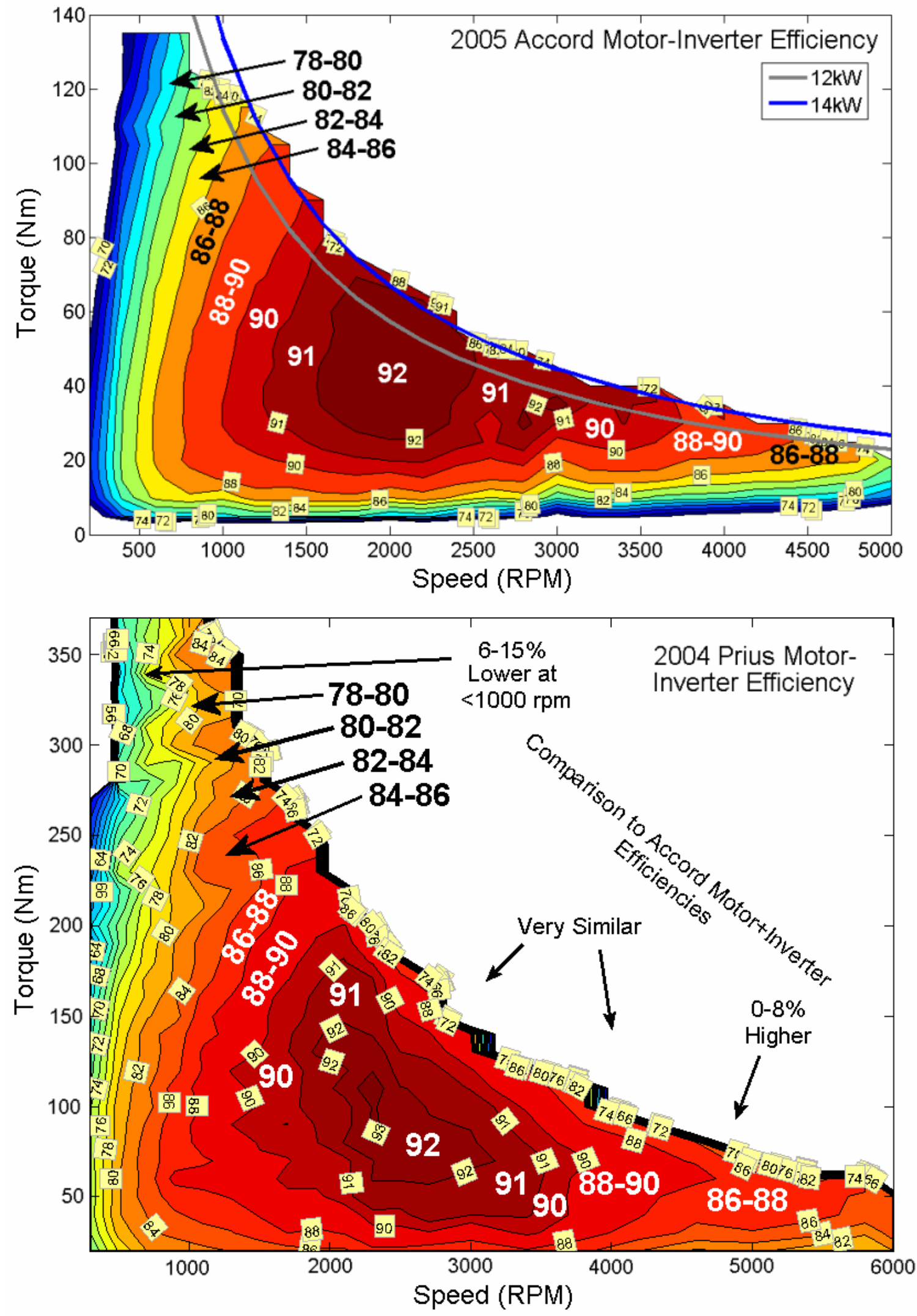

Fig. A.3. Comparison of Accord and Prius motor plus inverter efficiency contour maps. 


\section{DISTRIBUTION}

Internal

1. D. J. Adams

2. T. A. Burress

3. C. W. Ayers

4. E. C. Fox

5. K. P. Gambrell
6. J. S. Hsu

7. L. D. Marlino

8. M. Olszewski

9. R. H. Staunton

10-11. Laboratory Records

\section{External}

12. T. Q. Duong, U.S. Department of Energy, EE-2G/Forrestal Building, 1000 Independence Avenue, S.W., Washington, D.C. 20585

13. R. R. Fessler, BIZTEK Consulting, Inc., 820 Roslyn Place, Evanston, Illinois 60201-1724

14. K. Fiegenschuh, Ford Motor Company, Scientific Research Laboratory, 2101 Village Road, MD-2247, Dearborn, Michigan 48121

15. V. Garg, Ford Motor Company, 15050 Commerce Drive, North, Dearborn, Michigan 48120-1261

16. E. Jih, Ford Motor Company, Scientific Research Laboratory, 2101 Village Road, MD-1170, Rm. 2331, Dearborn, Michigan 48121

17. A. Lee, Daimler Chrysler, CIMS 484-08-06, 800 Chrysler Drive, Auburn Hills, Michigan 483262757

18. F. Liang, Ford Motor Company, Scientific Research Laboratory, 2101 Village Road, MD-1170, Rm. 2331/SRL, Dearborn, Michigan 48121

19. M. W. Lloyd, Energetics, Inc., 7164 Columbia Gateway Drive, Columbia, Maryland 21046.

20. Natalie Olds, USCAR, nolds@uscar.org

21. M. Mehall, Ford Motor Company, Scientific Research Laboratory, 2101 Village Road, MD-2247, Rm. 3317, Dearborn, Michigan 48124-2053

22. J. Rogers, Chemical and Environmental Sciences Laboratory, GM R\&D Center, 30500 Mound Road, Warren, Michigan 48090-9055

23. S. A. Rogers, U.S. Department of Energy, EE-2G/Forrestal Building, 1000 Independence Avenue, S.W., Washington, D.C. 20585

24. G. S. Smith, General Motors Advanced Technology Center, 3050 Lomita Boulevard, Torrance, California 90505

25. E. J. Wall, U.S. Department of Energy, EE-2G/Forrestal Building, 1000 Independence Avenue, S.W., Washington, D.C. 20585

26. B. Welchko, General Motors Advanced Technology Center, 3050 Lomita Boulevard, Torrance, California 90505

27. P. G. Yoshida, U.S. Department of Energy, EE-2G/Forrestal Building, 1000 Independence Avenue, S.W., Washington, D.C. 20585 